NBER WORKING PAPER SERIES

\title{
CONSOLIDATION OF BANKS IN JAPAN: CAUSES AND CONSEQUENCES
}

\author{
Kaoru Hosono \\ Koji Sakai \\ Kotaro Tsuru \\ Working Paper 13399 \\ http://www.nber.org/papers/w13399
}

NATIONAL BUREAU OF ECONOMIC RESEARCH

1050 Massachusetts Avenue

Cambridge, MA 02138

September 2007

We appreciate valuable comments from Andy Rose, Taka Ito, Hiro Ito, Barry Williams, and other participants at NBER EASE 18th Conference. The views expressed herein are those of the author(s) and do not necessarily reflect the views of the National Bureau of Economic Research.

(C) 2007 by Kaoru Hosono, Koji Sakai, and Kotaro Tsuru. All rights reserved. Short sections of text, not to exceed two paragraphs, may be quoted without explicit permission provided that full credit, including () notice, is given to the source. 
Consolidation of Banks in Japan: Causes and Consequences

Kaoru Hosono, Koji Sakai, and Kotaro Tsuru

NBER Working Paper No. 13399

September 2007

JEL No. G21,G34

\begin{abstract}
$\underline{\text { ABSTRACT }}$
We investigate the motives and consequences of the consolidation of banks in Japan during the period of fiscal year 1990-2004 using a comprehensive dataset. Our analysis suggests that the government's too-big-to-fail policy played an important role in the mergers and acquisitions (M\&As), though its attempt does not seem to have been successful. The efficiency-improving motive also seems to have driven the M\&As conducted by major banks and regional banks in the post-crisis period, while the market-power motive seems to have driven the M\&As conducted by regional banks and corporative (shinkin) banks. We obtain no evidence that supports managerial motives for empire building.

Kaoru Hosono

Gakushuin University

Faculty of Economics

Mejiro 1-5-1, Toshima-ku

Tokyo 171-8588 JAPAN

kaoru.hosono@gakushuin.ac.jp

Koji Sakai

Research Fellow of the Japan Society

for the Promotion of Science

2-1 Naka, Kunitachi

Tokyo 186-8601

Japan

ed042002@srv.cc.hit-u.ac.jp

Kotaro Tsuru

Research Institute of Economy, Trade, and Industry 1-3-1, Kasumigaseki, Chiyoda-ku

Tokyo, 100-8901, JAPAN

tsuru-kotaro@rieti.go.jp
\end{abstract}




\section{Consolidation of Banks in Japan: Causes and Consequences}

\section{Introduction}

Mergers and acquisitions (M\&As) among financial institutions have been accelerating over the last two decades across the world. These waves of mergers and acquisitions in the banking industries raise important questions of whether mergers enhance the efficiency of surviving banks and contribute to the stabilization of the banking sector or just increase their market power in setting prices. A large number of studies attempt to resolve these questions by examining profitability, cost efficiency and market performance of merger survivors. However, most of the existing studies examine the consolidation among the U.S. or European financial institutions and little is known about the causes and consequences of financial consolidation outside the U.S. or Europe.

This paper investigates the causes and consequences of the consolidation among Japanese banks. In Japan, a variety of banks have been consolidated since the 1990s when most banks suffered from a huge amount of non-performing loans.

The number of city banks, which operate nation-widely and internationally, remained at 13 during the 1980 s but decreased almost by half to 7 in 2005 . While the number of first-tier regional banks, which operate in one or a few prefectures, virtually did not change over the last two decades (63 in 1980 and 64 in 2005), the number of second-tier regional banks, which are smaller than first-tier regional banks and operate mainly within a prefecture, decreased from 71 in 1980 to 48 in 2005 . The number of cooperative 
(shinkin) banks, which are deposit-taking cooperatives operating within a prefecture and specializing in small and medium-sized enterprise (SME) loans, also dropped from 462 in 1980 to 301 in $2005^{1}$.

Using a rich dataset of bank M\&As in Japan, this paper comprehensively analyzes the causes and consequences of bank mergers in the following ways. First, we analyze motives of bank mergers as well as their consequences. Using ex-ante bank characteristics, we investigate what type of a bank was more likely to be a target or an acquirer. Looking at the post-merger performance of a consolidated bank, we examine the effects of mergers on the cost efficiency, profitability and healthiness. Though many preceding studies focus on profitability and cost efficiency, it would be important to examine whether bank consolidation improved bank healthiness or not, if regulatory authorities promote bank consolidation to stabilize the banking system. We measure long-run post-merger performance based on accounting ratios rather than stock market returns. Though market returns are relatively free from measurement errors associated with accounting ratios, analyzing them would severely reduce the sample size, given that many regional banks and all shinkin banks are not publicly traded. In addition, accounting ratios enable us to analyze important components of performance (e.g., cost efficiency or market power $)^{2}$. Finally, our observations are comprehensive. We use data

\footnotetext{
${ }^{1}$ City banks and regional banks are both corporations licensed under Bank Law, while shinkin banks are cooperatives of small and medium sized enterprises (SMEs) licensed under Shinkin Bank Law. Regional banks are classified into first-tier and second-tier regional banks according to the associations they belong to. There are usually one relatively large first-tier regional bank and some relatively small second-tier regional banks in one prefecture.

${ }^{2}$ We could analyze the impact of merger announcement on abnormal returns for the mergers of listed major banks (e.g., Okada, 2005). However, it would still be difficult to analyze the long-run
} 
of major banks (i.e., city banks, trust banks, and long-term credit banks, which operate nation-widely and internationally) and regional banks (i.e., first-tier regional banks and second-tier regional banks) over the period of fiscal year 1990-2004, and data of shinkin banks over the period of fiscal year 1990-2002. Our sample universe accounts for more than $80 \%$ share of deposits in all the depository institutions in $\mathrm{Japan}^{3}$. During the period of fiscal year 1990-2004, there were 10 mergers by major banks, 9 mergers by regional banks, and 97 mergers and 2 transfers of business among shinkin banks ${ }^{4}$, besides the mergers and transfer of business from failed banks.

The rest of the paper is organized as follows. Section 2 briefly reviews the existing literature on bank mergers. Section 3 discusses the hypotheses on the motivations of bank mergers. Section 4 analyzes the M\&A waves in Japan using aggregate data at the prefectural level. Section 5 describes our bank-level dataset. Section 6 analyzes the motivation of bank mergers using pre-merger bank characteristics data. Section 7 presents the post-merger performance concerning profitability, market power, cost efficiency, healthiness, and portfolio. Section 8 concludes.

performance of stock returns even for the mergers of listed major banks, because most of the consolidated major banking firms newly established holding companies that owned the share of other financial institutions (e.g., nonbanks, securities companies, and credit card companies). For the pitfalls of using short-run responses of stock market prices to merger announcement when mergers are a relatively new phenomenon, see Delong and Deyoung (2007).

3 As of March 2001, for example, the share of deposits at city banks, first-tier regional banks, second-tier regional banks, and shinkin banks are $29.2 \%, 25.5 \%, 8.2 \%$, and $15.1 \%$, respectively. Data source is Bank of Japan web site: www.boj.or.jp.

${ }^{4}$ No merger was conducted across different types of banks during the sample period, and there was one sale of business of a failed bank across bank types: the business of the failed city bank, Hokkaido Takushoku Bank, was sold to a regional bank, Hokuyo Bank and a trust bank, Chuo Trust Bank in 1997. 


\section{Literature review}

In the U.S., a large number of commercial and savings banks were taken over by other depository institutions during the 1980 s and especially after restrictions on intrastate and interstate banking were removed by the Riegle-Neal Interstate Banking and Branching Efficiency Act of 1994. Recently, financial conglomerates have emerged through a series of M\&As after restrictions on securities and insurance businesses by banks were lifted by the Gramm-Leach-Bliley Financial Service Modernization Act. In Europe, the emergence of the European Union in 1999 spurred consolidation of the financial services industry. In the crisis-hit Asian countries, foreign capital entry into the banking industry and government recapitalization promoted bank consolidation. These merger waves generated a vast literature on bank M\&As, especially for U.S. and European banks.

Berger, Demsetz and Strahan (1999) review existing research concerning the causes and consequences of the consolidation of the financial services industry. They point out that the evidence is consistent with increases in market power especially in the case of consolidation within the same market (in-market M\&As); improvements in profit efficiency, and diversification of risks, but little or no cost efficiency improvement on average; and potential costs to the financial system from increases in systemic risk or expansion of the financial safety net.

Okada (2005) studied 10 mega-mergers among city banks during 1989-2000 and found that no improvement in $\mathrm{X}$-inefficiency was observed but increases in cumulative 
excess stock returns and decreases in perceived default probability were found. Her results suggest that the motivation of mega-mergers was not to improve efficiency but to take advantage of the government's too-big-to-fail policy. Yamori, Harimaya and Kondo (2005) studied financial holding companies of regional banks and found that profit efficiency tended to increase when the market share in the region increased. Hosono, Sakai and Tsuru (2006) analyzed the motives and consequences of credit corporative (shinkin) banks during the period of $1984-2002^{5}$. Their major findings are as follows. First, less profitable and cost efficient banks were more likely to be an acquirer and a target. Second, acquiring banks improved cost efficiency but still deteriorated their capital-to-asset ratio after consolidation. Finally, the consolidation of shinkin banks tended to improve profitability when the difference in the ex-ante profitability between acquiring banks and target banks were large. This paper extends Hosono et al., (2006) to cover most Japanese banks, including city banks, first-tier regional banks, second-tier regional banks, and shinkin banks. Compared with the preceding studies on the consolidation of Japanese banks, this paper comprehensively analyzes the causes and consequences of bank mergers, as we mention in the Introduction.

\section{Hypotheses on the motives of bank consolidation}

This section reviews four major hypotheses on the motives of bank consolidation.

A. Improving efficiency

${ }^{5}$ See also Yamori and Harimaya (2005) for the study of the mergers of shinkin banks. 
As Berger et al., (1999) points out, the primary motive for consolidation would be maximizing the value of shares owned by existing shareholders. Banks can maximize value either by increasing their efficiency or by increasing their market power in setting prices. Cost efficiency will be improved if an efficient bank spreads its superior managerial skills to an inefficient bank by acquiring the latter. Profitability will be enhanced by superior risk management.

The efficiency improvement hypothesis suggests that an efficient bank tends to acquire or purchase the business of an inefficient bank.

\section{B. Strengthening market power}

Market power can be strengthened if two or more banks operating in the same market are consolidated and consequently the market becomes more concentrated. Existing evidences from the U.S. bank M\&As suggest that in-market M\&As, i.e., M\&As of banks operating in the same market, may increase market power in setting prices.

According to this hypothesis, banks operating in the same region are more likely to be consolidated. Actually, most of the M\&As among regional banks were conducted by banks operating in the same prefecture. Although all of the M\&As among corporative (shinkin) banks were also conducted by banks operating in the same prefecture, this fact does not necessarily imply the market power motive but may simply reflect the regulatory restriction under which shinkin banks are allowed to operate only in a region that is usually defined within a prefecture. 
C. Taking advantage of a too-big-to-fail policy

The government policy directly or indirectly affects banks' M\&A decisions. In particular, if regulatory authorities are expected to pursue a too-big-to-fail policy, weak banks have a strong incentive to be consolidated with each other, because bank managers may want to keep their positions. Bank shareholders can also gain from the value of deposit insurance by surviving through mergers.

The government can promote bank consolidations among weak banks in some ways. First, the government can "arrange" consolidations, persuading (or sometimes forcing) relatively healthy banks to acquire unhealthy banks. Second, the government can give weak banks incentives to be consolidated with each other by establishing a scheme for recapitalizing consolidated banks.

In Japan, the government's “arrangements" were sometimes used before the 1980s when the financial markets were heavily regulated, and even in the first half of the 1990s, as is known as the "convoy system" (see the next section for details). The "market-based" consolidation through public money injection has become an alternative tool since 1998 when the banking crisis culminated and the government first recapitalized banks. When Japanese authorities recapitalized banks first in 1998, they did so towards major banks and two largest regional banks. This fact may have fostered banks' anticipation for bailouts as long as they were large. Not only a large bank that operates nation-widely, regional banks and corporative banks (shinkin) banks that are 
relatively large in a prefecture may have anticipated bailouts, because the Japanese regulatory authorities have often worried about the stability of regional financial systems, though the notion of a regional systemic risk had not been stipulated until the Deposit Insurance Act was revised in 2001 (Article 102) ${ }^{6}{ }^{7}$.

If the government's anticipated too-big-to-fail policy and local market stabilization policy affect the decision of M\&As, unhealthy banks or banks recapitalized by the government tend to be consolidated with each other.

\section{Managerial Empire Building}

When corporate governance structures are weak, managers may be willing to acquire other banks for the purpose of empire-building. They may gain personal financial and non-financial gains from consolidated institutions. Managerial hubris may also drive bank mergers (Bliss and Rosen, 2001).

Weak governance structures allow managers to spend on activities with scope for generating managerial private benefits, such as advertisement or entertainment expenditures (Yafeh and Yosha, 2003). Therefore, we may expect that banks that spend more on advertisement or entertainment tend to acquire other banks. In addition, if managerial empire building motive drives M\&As, then a consolidated bank cannot realize efficiency gains, and is not willing to downsize or restructure the business.

\footnotetext{
${ }^{6}$ For example, when the largest regional bank in Tochigi Prefecture, Ashikaga Bank, was failing, the government temporarily nationalized it to avoid a regional systemic risk.

7 Though the government has not recapitalized shinkin banks so far, this does not necessarily mean that the government does not care about the stability of the local financial market. It has not been necessary for the government to recapitalize shinkin banks because the central financial institution of shinkin banks, called Central Shinkin Bank, recapitalized member shinkin banks when necessary.
} 
Managers of consolidated banks may increase advertise expenditures for their private benefits.

\section{Bank Merger Wave in Japan}

\subsection{Overview}

A very small number of mergers occurred in the banking industry until the 1980s after the World War II in Japan. The number of city banks, which operate nation-widely and internationally, had been 13 until $1990^{8}$. Mergers among regional banks, which operate mainly within a prefecture, also had been rare until the 1990s. Only one mutual bank (former second-tier regional bank) was acquired in the 1970s and two mutual banks were acquired in the 1980s. ${ }^{9}$ Mergers among credit corporative banks (shinkin) did not occur frequently, either. A small number of mergers until the 1980s reflected the government's so-called “convoy system" policy ${ }^{10}$. Under this policy, the regulatory authorities tried to stabilize the banking system by restricting competition among banks and bailing out failing banks. The government restricted banks' opening new branches and prohibited banks from engaging in securities business to control competition. When a weak bank fell into financial distress, the government requested a healthy bank to rescue the weak bank by injecting capital and sending directors. Healthy banks responded to the government's request because they could obtain the branch networks of

\footnotetext{
8 Mitsui Bank acquired Taiyo Kobe in 1990.

9 Hirosaki Sogo Bank was acquired by Seiwa Bank in 1976. Takachiho Sogo Bank was acquired by Nishinippon Sogo bank in 1984. Heiwa Sogo Bank was acquired by Sumitomo Bank in 1986.

${ }^{10}$ For the details of the convoy system, see Hoshi and Kashyap (2001). For a typical example, Ministry of Finance asked Sumitomo Bank to acquire the failing Heiwa Sogo Bank and Sumitomo responded to it so as to obtain the branch network of Heiwa Sogo.
} 
the failing banks. Until the 1980 s, M\&As in the banking industry occurred only when the government requested healthy banks to acquire failing banks.

As the financial liberalization was made progress in the $1980 \mathrm{~s}$, the regulatory authorities found it more and more difficult to maintain the convoy system; healthy banks had little incentive or capability to rescue failing banks. In the early 1990s, stock prices and land prices fell sharply, which hit hard banks' asset quality. Risk-based capital requirements based on the Basel capital standards, introduced in fiscal year 1992, spurred consolidation of weak banks. Two mergers among city banks ${ }^{11}$ and three mergers among regional banks occurred in the first half of the 1990s (Table 1). Mergers among shinkin banks also occurred more frequently in the 1990s than before. Despite the introduction of the Basel capital standards, which were supposed to be rule-based regulations, financial regulations and supervisions by Ministry of Finance were still affected by political pressure until a banking crisis occurred in $1997^{12}$.

A banking crisis occurred in 1997, when three large financial institutions, including a city bank named Hokkaido Takushoku Bank, failed. In 1998, two long-term credit banks named the Long-Term Credit Bank of Japan and the Nippon Credit Bank failed. In response to the severe banking crisis, the Japanese regulatory authorities introduced prompt corrective actions in 1998, applied stringent accounting standards in implementing the Basel capital standards, and recapitalized banks to promote their

11 Taiyo Kobe Bank was acquired by Mitsui Bank in 1990 and Saitama Bank was acquired by Kyowa Bank in 1991.

${ }^{12}$ The government's resolutions of the failed "Jusen," nonblank finance companies specialized in housing and real estate loans, were severely criticized by the public that the government rescued agricultural cooperatives that had invested in Jusen and had a strong political influence (See Hoshi and Kashyap, 2001). 
restructuring. Financial Supervision Agency (FSA) was built and took over financial supervisions from Ministry of Finance in 1998. FSA refrained from "arranging” mergers, not intervening in bank mergers to rescue weak banks.

Major banks tried to survive through mergers, resulting in the merger wave in the early 2000s. Financial Rehabilitation Plan, released by Takenaka, Minister of Financial Services Agency, in October 2002, forced major banks to apply strict accounting standards and to reduce their non-performing loan share to a half, urging weak banks to be consolidated.

Seven mergers among major banks occurred from FY 2000 to FY 2002. Mega banks are now reorganized into three groups (Mizuho, Mitsui-Sumitomo, and Mitsubishi-UFJ). The government also promoted consolidation of regional banks and shinkin banks. New legislation has enabled the government to recapitalize a consolidated bank since $2002^{13}$. Six mergers among regional banks occurred from FY 2000 to FY 2004. Merges among shinkin banks also accelerated in the early 2000s (Table 1).

\subsection{Empirical analysis}

We first investigate the reasons for the recent merger wave using the M\&A ratios, i.e., the numbers of M\&As divided by the total number of banks existing in the previous year, sorted by prefectures and bank types. The hypotheses concerning the motives of

${ }^{13}$ Special Measures Law for the Promotion of Financial Institutions Reorganization was enacted in October, 2002. Under this law, the government recapitalized Kanto Tsukuba Bank in September 2003. Financial Function Reinforcement Law was enacted in April 2004 to enable the government to preemptively capitalize healthy regional and shinkin banks. Under this law, Kiyo Holdings and Howa Bank were recapitalized in 2006. 
bank mergers discussed in Section 3 have some implications concerning the time when and the space where M\&A waves occur.

First, if M\&As are driven by the motivation for improving efficiency, then merger waves result from shocks to an industry's economic, technological or regulatory environment (e.g., Mitchell and Mulherin, 1996). These shocks lead to industry reorganization. Analyzing the U.S. industrial merger waves in the 1980s and the 1990s, Harford (2005) found that operational performances measured by ROA, sales growth and others, were high prior to merger waves. He also found that higher market valuations relaxed financing constraints and made it easier to implement efficiency-driven M\&As. ${ }^{14}$ Following Harford (2005), we use the average ROA for each bank type to capture the economic shocks to the industry's operating environment, and the stock price index for the banking industry to capture the degree of financial constraints.

Second, if M\&As are driven by the motivation for strengthening market power, banks operating in a less concentrated and more competitive market are more willing to merge each other. Given that banks often compete within a region ${ }^{15}$, we use the Herfindahl index for the deposits of regional banks and shinkin banks calculated for each prefecture.

Third, if M\&As are driven by the motivation for taking advantage of a

\footnotetext{
${ }^{14}$ Shleifer and Vishny (2003) argue that stock market overvaluation promotes corporate managers to acquire relatively undervalued firms. This "behavioral" hypothesis also suggests that higher share prices cause merger waves. However, most of bank mergers in Japan have not been carried out through tender offers (take-over-bids) paying with stocks. So, we do not discuss the possibility of the behavioral hypothesis in details in this paper. For the empirical evidences of the "neoclassical" and "behavioral" hypothesis applied to Japanese non-financial firms, see Arikawa and Miyajima (2007).

${ }^{15}$ For the empirical evidences in Japan, see, e.g., Kano and Tsutsui (2003)
} 
too-big-to-fail policy or a local market stabilization policy, then merger waves occur when the overall bank health is deteriorated. To capture the bank healthiness, we use the average capital-to-asset ratio for each bank type. The change in the stock price index for the banking industry also serves as a proxy for bank healthiness. Unlike the efficiency-motive hypothesis, the hypothesis concerning a too-big-to-fail policy suggests that a lower stock price triggers a bank merger. A low ROA may also lead to a merger under the too-big-to-fail-policy hypothesis, because a low ROA deteriorates bank health.

Finally, if M\&As are driven by the managerial motives for private benefits, then M\&As are more likely to occur when and where the average expenditures for managerial private benefits such as advertisement expenditures or entertainment expenditures are high. While major banks and regional banks disclose advertisement expenditures, shinkin banks do not disclose the components of operational costs such as advertisement expenditures. Therefore, we cannot test the managerial motives hypothesis using the prefecture-level data here.

To control for regional shocks that affect banks' operating environment, financial constraints for M\&As, and bank healthiness, we add the growth rate of prefectural GDP to the explanatory variables ${ }^{16}$. We also include a time dummy that takes the value of unity in and after fiscal year 1998 and zero before fiscal year 1997 to capture the regulatory changes stated in the previous section. The estimation period is from fiscal year 1990 to fiscal year 2004 .

We estimate the following equation.

16 Major banks had head offices in Tokyo, Nagoya, Sapporo or Osaka. 


$$
\begin{aligned}
M \& \text { A }_{\text {Ratio }_{i, j, t}} & \beta_{1} \text { Averagege Performance }_{i, j, t-1} \\
& +\beta_{3} \text { Herfindahl Index }_{i, t-1}+\beta_{4} \text { GDPGrowth }_{i, t-1}+\beta_{5} \text { PostCrisisDummy }_{t} \\
& +\beta_{6} \text { PostCrisisDummy }_{t} * \text { Average Performance }_{i, j, t-1}+\varepsilon_{i, j, t}
\end{aligned}
$$

, where indexes $i, j, t$, are a prefecture, a bank type, and a fiscal year, respectively. Average Performance is either the average ROA, the average capital-to-asset ratio calculated for each prefecture, or the change in the stock price index for the banking industry. We do not enter those three variables at a time, because they are highly correlated. Herfindahl Index is calculated based on the shares of deposits of regional and shinkin banks in a prefecture. GDP growth is the growth rate of the GDP of the prefecture where the head office locates. Because GDP growth is highly correlated with stock price index, we do not enter them at the same time. We allow for the change in the coefficients of the bank performance variables after the crisis using the interaction term of the post-crisis dummy and the performance variables.

Table 2 reports the pooled-OLS regression estimates of Equation (1). Though we also estimate the model with a fixed or random prefectural effect, we report the pooled-OLS model based on the specification tests. First, when the average ROA is included as a performance measure (column 1), the coefficients on ROA and its interaction term with the post-crisis dummy are both negative, though neither is significant. This is not consistent with the efficiency-driven hypothesis. Next, looking at the case where the average capital-to-asset ratio is used (column 2), we see that the coefficients on the capital-to-asset ratio and its interaction term with the post-crisis 
dummy are both negative, though only the interaction term is significant. Finally, using the stock price index yields the result (column 3) that its coefficient is negative and significant, while its interaction term is positive but not significant. These results suggest that M\&As tended to occur when the overall bank health was deteriorated, consistent with the too-big-to-fail or stabilization policy hypothesis. The coefficients on the Herfindahl index are negative and significant, regardless of the bank performance measures, suggesting that M\&As tended to occur where the market was less concentrated, which is consistent with the market-power hypothesis. The coefficients on the GDP growth are significantly negative, which is again consistent with the too-big-to-fail or the financial stabilization policy hypothesis. Finally, the post-crisis dummy is positive and significant, suggesting that the regulatory changes triggered bank consolidations.

We will examine the relevance of the four hypotheses concerning the motives of M\&As more closely using bank-level data in the following sections.

\section{Bank-Level Data}

The data source of financial statements of major banks and regional banks is Nikkei Financial Quest and that of shinkin banks is Financial Statements of Shinkin Banks in Japan, edited by Financial Book Consultants, Ltd. (Kinyu tosho konsarutanto sha). We identify an acquirer if the bank is legally surviving and a target if the bank has legally disappeared. We focus on the mergers and acquisitions of surviving banks by 
excluding from our dataset the transfers of business from a failed bank, because the latter is likely to be conducted for different motives and to have different consequences ${ }^{17}$. Our dataset covers the period of fiscal year 1990 to 2004 (i.e., from March 1991 to March 2005) for major and regional banks and fiscal year 1990 to 2002 (i.e., from march 1991 to March 2003) for shinkin banks. For the details of the variables we use, see Appendix 1.

In Japan, financial holding companies were allowed to be built since 1998 when the Antimonopoly Act was revised. Some consolidated banks, especially major banks and large regional banks, took that opportunity to form a financial holding company that held insurance companies and nonbank financial companies as well since 2000 . In the case of holding companies, we use the financial statements of the subsidiary banking companies. We do not use the stock prices of the financial holding companies because they reflect the performance of the other subsidiary companies as well. By using the financial statement of the subsidiary banking companies, we focus on the effects of mergers on the banking company. If there is a synergy effect from the security companies to the banking company within the same holding company, it is reflected by the financial statement of the banking company.

In the following analyses, we divide the sample banks into major banks (city banks, long-term credit banks ${ }^{18}$, and trust banks), regional banks (first-tier regional

17 The transfer of business from a failed bank is identified if the deposit insurance made financial assistance (not recapitalization) to the bank that acquired or purchased the business of another bank. ${ }^{18}$ Long-term credit banks are those banks that were established for the purpose of long-term corporate finance and permitted to issue long-term bonds exclusively under Long-term Credit Bank Law. Though three long-term credit banks were established after WWII, two of them (i.e., Long-Term 
banks and second-tier regional banks), and shinkin banks for the following reasons. First, a shinkin bank is a cooperative depository institution specialized to small- and mediumsized enterprise (SME) finance. Therefore, the motives and consequences of M\&As might be different from corporations like major banks and regional banks. Second, while major banks operate nation-widely, regional banks and shinkin banks operate mainly within a prefecture. Most of the M\&As among regional banks and shinkin banks were conducted by those banks that operated within the same prefecture (in-market merger) ${ }^{19}$. The effects of mergers on market power might be different between major banks and regional or shinkin banks. Third, regulatory authorities' attitudes towards the non-performing loan problems were different between major banks, on one hand, and regional and shinkin banks, on the other hand, in the late 1990s and the early 2000s. The government aimed at quickly reducing the non-performing loans of major banks, while the government, afraid from the adverse effect of the write-off of non-performing loans on SME finance, did not force regional and shinkin banks to reduce non-performing loans quickly. Because the number of mergers by major banks and regional banks are small (10 and 9, respectively), separating them may yield relatively weak statistical results. However, we choose not to pool the major banks and regional banks because of the above reasons.

Table 3 shows the descriptive sample statistics of the bank and market

Credit Bank of Japan and the Nippon Credit Bank) failed in 1998, and one (i.e., Industrial Bank of Japan) was merged with city banks (Fuji Bank and Daiichi-Kangyo Bank) and reorganized in 2002.

${ }_{19}$ Among the M\&As by regional banks or shinkin banks, only four (two M\&As by regional and two M\&As by shinkin banks) were conducted across prefectural borders. 
characteristics that we use in the following analyses. We compare the bank characteristics variables among the acquirers, targets, and the average of each bank type: major banks, regional banks, and shinkin banks. The variables of the acquirers and the targets are as of one-year before the mergers. Though we do not control for macroeconomic shocks across different years in Table $3,{ }^{20}$ it provides some useful information concerning the ex-ante characteristics of acquires and targets. First, targets and acquirers are less capitalized than the average of each bank type, and the differences in the risk-based capital ratios are significant in the case of the mergers of regional banks and shinkin banks. Second, the acquirer tends to be larger and the target tends to be smaller than the bank-type average, with the exception of the major banks' targets, though the differences in the logarithm of total assets are significant only in the case of shinkin banks. Finally, in the case of the M\&As of shinkin banks, the targets' ROA are significantly lower than the average.

Figure 1 compares some characteristics of acquirers and targets as compared with the average of each bank type. We follow the following three-step process to draw Figure 1. First, observing the financial statements of the acquirer and the target for the five years preceding the merger, we combine these statements to create pro forma financial ratios for a hypothetical combined bank. To calculate hypothetical pre-merger financial ratios, we calculate the weighted average of the acquirer and the target, where the total

\footnotetext{
${ }^{20}$ The differences in the interest rates on deposits and loans, in particular, seem to reflect the fact that a large number of M\&As occurred in the latter half of the 1990s, when Bank of Japan conducted an extremely-low-interest-rate policy.
} 
assets of the acquirer and the target are used as a weight ${ }^{21}$. Second, we calculate the post-merger bank's financial ratios for the actual combined bank using its financial statements for five years after the merger. Third, we normalize both the pre-merger and post-merger financial ratios of the acquirer and the combined bank, respectively, by subtracting off the same-year, bank-type average.

Those banks whose data is available at the merger year and a pre-merger year are included in the sample here. Similarly, those banks whose data is available at the merger year and a post-merger year are included in the sample here. In Figure 1, simple averages of bank characteristics are depicted. Because we cannot compare accounting variables as of the year of M\&As with the pre-merger or post-merger periods, we just connect a line for one year before M\&As and one year after M\&As. We look at the financial ratios that represent bank efficiency, market power, healthiness, and portfolio.

Figure 1A depicts the pre-merger and post-merger financial ratios of major banks, suggesting some interesting facts. First, target banks were less cost-efficient than the average and consolidated banks' ROA recovered slowly from an immediate deterioration after mergers. Second, consolidated banks increased the share of SME loans at least for the first three years after mergers. Third, the loan interest rate did not show a clear increasing tendency. Fourth, poorly capitalized banks tended to be an acquirer or a target, and that a consolidated bank suffered from decreasing capital ratios and increasing

\footnotetext{
${ }^{21}$ If three and more banks merged, the series of the targets are a weighted sum of the targets and the series of the hypothetical combined bank are a weighted sum of the targets and acquirers. In both series, we use total assets as weights.
} 
non-performing loans at least for three to four years after mergers ${ }^{22}$. Finally, both acquirers and targets spent less on advertisement expenses before mergers and consolidated banks continued to spend less on them after mergers than the average.

Figure 1B depicts the pre-merger and post-merger bank characteristics of regional banks. Like major banks, target banks were inefficient and poorly capitalized and that profitability and efficiency once deteriorated and then slowly recovered after consolidation. The recovery of bank health, measured by capital ratios or non-performing loans, after consolidation was also slow. Unlike major banks, consolidated banks decreased the share of loans to SMEs after mergers. Consolidated banks also decreased the advertisement expenses after mergers from a relatively high level before mergers.

Figure 1C shows the pre-merger and post-merger bank characteristics of shinkin banks. Like major banks and regional banks, target banks were inefficient and unhealthy. The recovery of profitability, cost efficiency, or healthiness could not be seen clearly after M\&As. Acquirers and targets tended to focus on traditional loan business before M\&As and a consolidated bank tended to focus more on loan business, unlike major banks. A consolidated bank raised the loan interest rate after M\&As.

In the following sections, we statistically examine how the pre-merger bank characteristics affected the M\&A decision and how M\&As changed bank performance.

\footnotetext{
${ }^{22}$ Non-performing loans (NPLs) defined by Bank Law are the sum of loans to failed borrowers, delinquent loans, loans delinquent for more than three months, and loans with the terms alleviated, all classified by each loan. NPLs defined by Financial Rehabilitation Law are all the claimable assets other than the normal ones whose debtors have no financial problems, classified by debtors' financial conditions. Banks are required to disclose both types of NPLs.
} 


\section{Ex-ante Characteristics and the Decision of Consolidation}

If efficiency improvement motives drive consolidation, relatively profitable and efficient banks would tend to acquire relatively unprofitable and inefficient banks in order to spread superior expertise and management skills over the target bank. On the other hand, if the government's too-big-to-fail policy or its motives of stabilizing the nation-wide or local banking system drive consolidation, relatively unhealthy banks tend to be consolidated with each other. The government may also promote consolidations through recapitalization. If managerial private incentive for empire-building is a major motive for mergers, banks that spend more on private benefits like advertisement expenditures are more likely to acquire other banks.

To analyze the motives for consolidation, we estimate the multinomial logit model:

$$
P_{t, j}=\frac{\exp \left(\beta^{\prime} X_{t-1, j}\right)}{\sum_{j=1}^{3} \exp \left(\beta^{\prime} X_{t-1, j}\right)} \text { for } j=1,2,3
$$

, where $P_{t, j}$ is the probability of the bank's choosing the variable $j$ at time $t$, with $j$ being an acquirer, a target, or neither. The dependent variable vector $X_{t-1, j}$ consists of bank profitability, efficiency, healthiness, governmental recapitalization, managerial private benefits, and size as well as other control variables including market concentration and macroeconomic variables. We choose the ROA and the cost ratio for the efficiency variables, and the capital-to-asset ratio and the non-performing loans as a 
proportion of total loans as bank health measures. Non-performing loans is available only after 1998. We also use the yearly change in the stock prices as bank health measures in the case of major banks, though the stock price data of individual bank is available only up to 2001, because since then major banks established holding companies whose subsidiaries include security companies and non-banks as well. The governmental recapitalization is captured by a dummy variable that takes the value of one if the bank has been recapitalized that year or before and zero otherwise. As a measure of private benefits, we use the advertisement expenses as a proportion of total cost. For the size variables, we use the logarithm of total assets and the growth rate of total assets. As a degree of market concentration, we use the Herfindahl index for regional banks and shinkin banks. Though major banks had head offices in Tokyo, Osaka, Nagoya or Sapporo and had some operational advantages over the areas where the head offices were located, they had branches and operated nation-widely. This is why we do not use the prefectural Herfindahl index in the case of major banks. We control for the experience of M\&As using a dummy variable that takes the value of one if the bank has experienced a M\&A before and zero otherwise. A bank that has experienced a M\&A before may not want to carry out another M\&A if it takes a long time to consolidate information systems and other business cultures. On the other hand, a bank that has experienced M\&As may have knowledge and skills how to efficiently integrate different business practices. In that case, the M\&A experience dummy has a positive effect on the probability of being an acquirer. Finally, to control for industrial or macroeconomic 
shocks, we add the change in the stock price index for the banking industry and the growth rate of GDP in the case of major banks, and the growth rate of prefectural GDP in the case of regional and shinkin banks. All the explanatory variables are lagged by one-year.

We checked the correlation among the explanatory variables and found that ROA and the capital-to-asset ratio are strongly correlated for regional banks and shinkin banks (The correlation coefficients are $0.045,0.853$, and 0.615 for major banks, regional banks and shinkin banks, respectively.) To check the robustness, we also estimate Eq. (2) by entering ROA and the capital-to-asset ratio one by one into the explanatory variables. In addition, to take into consideration the possibility that it took more than one year to prepare for mergers, we also present the estimation results in the case of two-year lagged dependent variables ${ }^{23}$.

We estimate Eq. (2) for each bank type: major banks, regional banks, and shinkin banks. In addition to the full sample period (FY 1990-2004), we divide the sample period into the pre-crisis period (FY 1990-1997) and the post-crisis (FY 1998-2004). The regulatory authorities did not intervene in bank mergers to rescue weak banks in the post-crisis period. Furthermore, their attitudes toward major banks' non-performing loan problems became much severer in the post-crisis period than in the pre-crisis period. It would be useful to see whether there would be difference in the

\footnotetext{
${ }^{23}$ Two-year lagged dependent variables may be appropriate in case that a bank that is to be acquired by a relatively healthy bank in two years gambles on high-risk high-return investment and finally deteriorates its balance sheet one-year before mergers. This potential moral hazard problem was pointed out by Hiro Ito.
} 
motives of bank mergers between the pre- and post- crisis periods.

\section{Major banks}

Table 4A shows the estimation results for major banks. Column 1 shows the estimated coefficients and column 2 shows the estimated marginal effects ${ }^{24}$ for the full sample period. Looking at the results of the acquirer equation, we see that the coefficient on the governmental capital injection dummy is positive and significant, suggesting that those major banks that had been recapitalized by the government were more likely to be consolidated. This result is consistent with the too-big-to-fail policy or stabilization policy hypothesis. It should be noted, however, that because all the major banks were recapitalized by the government in 1998, the coefficient on the governmental capital injection dummy may reflect any structural changes after 1998. The other bank characteristics variables and macroeconomic variables are not significant. Turning to the target equation, we see that the coefficient on the industrial stock price index is negative and significant, suggesting that a bank was more likely to be acquired when the equity values of the banking industry were deteriorated. These results are consistent with the too-big-to-fail policy or the stabilization policy hypothesis.

Entering ROA and the capital-to-asset ratio one by one into the explanatory variables, we obtain similar results (shown in columns 3 to 6), though the coefficient on the governmental capital injection dummy is positive and significant in the target equation when only ROA is entered.

${ }^{24}$ The average marginal effects are reported here (Wooldridge, 2001, pp.467). 
Columns 7 and 8 show the results when the changes in individual banks' stock prices are used as a bank health measure. We see that its coefficient is not significant in the acquirer or target equation. In the case of major banks, the overall worsening of bank heath and the government's response to a systemic risk may have driven the merger waves rather than the individual bank health.

Using two-year lagged explanatory variables, we see (in columns 9 and 10) that no explanatory variable is significant in the acquirer or the target equation, except for the capital-to-asset ratio in the target equation that is positive and significant. Though this result is not consistent with the too-big-to-fail policy hypothesis, two-year lagged dependent variable may not be suitable in the case of the mergers of major banks, because every major bank seemed to hasten to choose the bank to consolidate or to be consolidated by especially in the post-crisis period.

The sub-period estimation results are presented in columns 11 to 14 . While no pre-merger variable is significant in the pre-crisis period, the coefficient on the cost ratio is positive and significant in the target equation in the post-crisis period. The fact that a less cost-efficient major bank tended to be acquired by other banks in the post-crisis period is consistent with the efficiency-improving hypothesis.

\section{Regional banks}

Table 4B shows the estimation results for regional banks. Looking at the full sample period estimation result, we see that the coefficients on the governmental capital 
injection dummy are positive and significant in both the acquirer and target equations, which supports the too-big-to-fail policy or stabilization policy hypothesis. In the target equation, the coefficient on the (logarithm of) asset is negative and significant, suggesting that a smaller regional bank was more likely to be a target. These results hold even if we enter ROA and capital-to-asset ratio one by one and if we use two-lagged dependent variables (columns 3 to 8 ). Looking at the sub-sample period estimation results (columns 9 to 12), we see that no pre-merger variable is significant in the pre-crisis period. On the other hand, in the post-merger period, the coefficient on ROA is positive and significant and the coefficient on capital-to-asset ratio is negative and significant in the acquirer equation, while none is significant in the target equation. The result for the acquirer equation in the post-crisis period is consistent both with the efficiency-improving hypothesis and the too-big-to-fail policy or stabilization policy hypothesis.

\section{Shinkin banks}

Table 4C displays the estimation results for shinkin banks. We exclude advertisement expenses from the explanatory variables because shinkin banks do not disclose them. Looking at the full sample period estimation result of the acquirer equation (columns (1) and (2)), we see that the coefficients on the (logarithm of) asset and the M\&A experience dummy are positive and significant. A larger shinkin bank is more likely to acquire another shinkin bank. In the target equation, the coefficient on 
ROA is positive and significant and the coefficient on the cost ratio is negative and significant. Efficient shinkin banks tended to be a target, though the efficiency-improving hypothesis posits that efficient banks tend to be an acquirer. The coefficient on the capital-to-asset ratio is negative and significant, which is consistent with the too-big-to-fail or stabilization policy. The coefficient on the Herfindahl index is negative and significant, suggesting that a shinkin bank tends to be consolidated if it operates in a less concentrated market, which is consistent with the market power hypothesis. The coefficients on the (logarithm of) asset and the asset growth are both negative and significant, suggesting that a small or slowly growing shinkin bank tended to be a target.

Most of these results still hold even if we enter ROA and the capital-to-asset ratio separately (columns (3)-(6)) or if we use two-year lagged dependent variables (columns (7) and (8)), though the coefficients on ROA and the capita-to-asset ratio become insignificant in the target equation when we enter them separately.

Though the sub-sample period estimation results yield similar results both in the pre-merger and post-merger periods, it is notable that the coefficient on the capital-to-asset ratio is negative and significant in the target equation only in the post-crisis period, suggesting that the too-big-to-fail or stabilization policy hypothesis is valid in the post-crisis period. The coefficient on the non-performing loan ratio is also positive and significant in the target equation in the post-crisis period. The evidences on the effects of the pre-merger bank efficiency on the likelihood of being a target are mixed; the signs of the coefficients on ROA change from negative in the pre-crisis period 
to positive in the post-crisis period, and the coefficient on the cost ratio is negative and significant in the pre-crisis period.

In sum, the efficiency-improving hypothesis seems to be valid in the case of the post-crisis period's consolidations among major banks and among regional banks. The market power hypothesis seems to be valid in the case of the consolidations among shinkin banks. The government's too-big-to-fail or financial stabilization policy hypothesis also seems to be valid especially in the case of the post-crisis period's consolidations. We find no evidence that supports the managerial empire-building hypothesis, though we cannot test that hypothesis in the case of the consolidations among shinkin banks due to the lack of suitable data.

\section{Post-Merger Performance}

\subsection{Background}

Consolidation may have various effects on the consolidated bank's efficiency, market power, services provided, healthiness and expenses for managerial private benefits.

First, consolidation may increase or decrease efficiency in various ways. A consolidated bank may be able to achieve a scale or scope economy. It may also improve X-efficiency by spreading superior acquirers' managerial skills over targets. On the other hand, it may take considerable time and costs to integrate different accounting and 
information systems, ways of doing business, and corporate cultures.

Second, consolidation may change the availability of loans and other financial services to small- and medium-sized enterprises (SMEs), though such changes may not be intended either by acquirers or targets. If consolidation improves efficiency, a more efficient consolidated bank may be able to serve more customers, including SMEs. On the other hand, if a large bank may find it costly to process relationship-based information due to its organizational complexity, a consolidated bank may reduce loans to the SMEs that are informationally opaque (Berger et al., 1999). Consolidated banks may also increase or reduce other services, including fee businesses, according to their comparative advantages.

Third, consolidation may strengthen market power, enabling the consolidated bank to raise loan interest rates or lower deposit interest rates. This is likely to occur when acquires and targets operated within the same local market (e.g., Berger et al., 1999).

Fourth, consolidation may improve or deteriorate healthiness. Although regulators may promote consolidations by weak banks, it is not clear whether weak banks can restore healthiness just through consolidation. On one hand, a consolidated bank may gain from risk diversification through investing various areas and industries (Berger et al., 1999). In addition, an acquirer may apply its superior risk management skills to a target. However, if poorly-capitalized banks are consolidated, a consolidated bank must be highly profitable to fill in the initial shortage of capital and then to recover its capital to a normal level, unless it raises capital from outside. In addition, a consolidated bank 
may be exposed to the risk of an unproportionally large amount of loans to some specific large borrowers as compared with other banks as a result of the consolidation. ${ }^{25}$

Finally, consolidation may increase or decrease expenses for the purpose of managerial private benefits, like advertisement expenses. If a bank acquires another bank for the purpose of increasing private benefits, a consolidated bank may increase expenses for private benefits. On the other hand, if a bank becomes a target due to its weak governance structures that allow large amounts of spending for private benefits, a consolidated bank may decrease such spending.

\subsection{Methodology ${ }^{26}$}

We investigate the consequences of M\&As by comparing the bank financial variables of pre-merger and post-merger periods. From the viewpoint of existing shareholders (or members of shinkin banks) of acquirers, it is natural to compare pre-merger acquiring banks and post-merger consolidated banks. On the other hand, from the viewpoint of regulators that care about the banking system, it is useful to compare hypothetical pre-merger combined banks (that is, a weighted average of an acquirer and a target) and post-merger consolidated banks. We perform both comparisons.

Specifically, we first construct the financial ratios of the pre-merger hypothetical

${ }^{25}$ The following example may be useful. Tokai Bank, Sanwa Bank, Fuji bank and Sumitomo Bank each had almost equal amounts (more than 500 billion yens) of loans outstanding to a large retail company, Daiei, which was in financial distress. It is said that UFJ Bank, formed from the consolidation of Tokai Bank and Sanwa Bank, was saddled with a distinguished amount (more than one trillion yens) of loans to Daiei for a long time after the consolidation.

${ }^{26}$ The approach here is similar to Delong and Deyoung (2007). 
combined bank and the post-merger consolidated bank in the same way as we depicted Figure 1. Note that we normalize all the pre-merger and post-merger financial ratios by subtracting off the same-year, bank-type average. Next, we take the pre-merger average of the hypothetical combined bank over the five years before mergers. If the pre-merger data is available for less than five years, we take the pre-merger average over the maximum years for which we can observe the data. Finally, we take the difference between the normalized pre-merger bank financial ratios and the normalized post-merger bank financial ratios. We look at the changes of the bank financial ratios for one to five years after mergers, respectively, though we report in Table 5 only three and five years after mergers to save space. Focarelli and Panetta (2003), Focarelli and Pozzolo (2005), and Rhoades (1998) show that a 2-3 year post-merger period is needed to determine if there are any post merger gains. We also take the average of the post-merger financial ratios of the consolidated bank over the (at most) five years after mergers and take the difference between the pre-merger 5-year average and the post-merger 5-year average.

We perform the t-test for the null hypothesis that the difference between a normalized pre-merger financial ratio and a normalized post-merger financial ratio has mean zero. We also performed the Wilcoxon signed-rank test (z-statistic) for the null hypothesis that the difference between them has median zero and obtained qualitatively similar results for most financial ratios. So, we mainly report the t-test results below.

In this section, we select a sample where data on bank financial ratios are available for the merger year, one or more pre-merger years, and one or more post-merger years. 
The dataset here is slightly different from that used in Figure 1, where we choose sample banks whose data were available for the merger year and one or more pre-merger years but not necessarily available for post-merger years and sample banks whose data were available for the merger year and one or more post-merger years but not necessarily available for pre-merger years.

\subsection{Results}

Major banks

Table 5A shows the changes in the financial ratios of the consolidated major banks. The first column shows the changes from the hypothetical pre-merger combined bank for the full sample period.

Looking at the efficiency variables, we see that the changes in ROA are negative three years after mergers and then turned to positive five years after mergers, though none of the changes is significant. The changes in the cost ratio are not significant, either, though consolidated banks seem to have decreased the cost ratio. It seems to take considerable time for a consolidated bank to realize cost savings or gain economies of scale or scope.

Market power variables show that the changes in the average deposit interest rate and the changes in the loan interest rate are not significant. A consolidated major bank did not seem to be able to exert market power in the deposit or loan market. This is not surprising, given that both acquiring major banks and target major banks operated 
nation-widely.

Business scope variables suggest that the share of SME loans significantly increases three years after mergers. One possible reason is that acquirers may have spread its skills necessary to make SME loans to targets. However, more plausible reason is that when the government recapitalized banks, it required banks to increase SME loans. Because banks tended to be consolidated after the government recapitalization, consolidated banks increased SME loans. This result is different from U.S. bank merger evidences, especially for the mergers of large banks (Berger et al, 1999, pp.170). The changes in fees and commissions and in the loan-to-asset ratio are not significant.

Bank health measures suggest that the changes in the capital-to-asset ratios are negative and significant three years after mergers and the changes in the risk-based BIS capital ratios are also negative and significant (for t-statistics) for three years after mergers. The improvement of ROA after the merger was not quick or sufficient enough to offset the initial gap of the capital ratios between consolidated banks (i.e., acquirers and targets) and their peers. In addition, the changes in the non-performing loan ratios, based either on Bank Law or Financial Rehabilitation Act, are positive and significant 3 years after mergers. Consolidated banks may have applied a stricter standard to recognize non-performing loans than before, resulting in the increase in disclosed non-performing loans. It is well known that Japanese banks often manipulated the amounts of disclosed non-performing loans so that they could satisfy the Basel capital standards before the Financial Rehabilitation Plan (i.e., Takenaka Plan) in 2002. In 
addition, a consolidated bank may have been exposed to the risk of an unproportionally large amount of loans to some specific large borrowers as a result of the consolidation. When those borrowers fell in financial distress, the consolidated bank may have continued to lend to them in order to avoid their failures, which would cause a sharp decrease in the bank's own capital. ${ }^{27}$

Finally, private benefit variables suggest that the change in the advertisement expenses as a proportion of total assets is not significant. The consolidated bank did not significantly increase advertisement expenses. In addition, the change in the average loan growth rate over the post-merger five years is significantly negative. The change in the average asset growth rate is also negative, though not significant. These results suggest that mergers triggered asset restructuring. Considering these results together, we may say that no evidence is found that support the managerial empire building hypothesis.

The second and third columns of Table 5A report the changes in the post-merger performance from the hypothesized pre-merger combined bank for the sub-periods of the pre-crisis period (FY 1990-1997) and the post-crisis period (FY1998-2004), respectively. In the pre-merger period, the change in the share of SME loans is significantly positive. On the other hand, in the post-merger period, the changes in the loan growth rate, the asset growth rate, and the capital ratio are significantly negative and the change in the non-performing loan ratio based on the Bank Law is significantly positive. The mergers in the post-merger crisis period seem to have been more directed to asset restructuring

${ }^{27}$ Such a behavior is called "ever-greening" (Peek and Rosen, 2005) or "zombie lending" (Caballero, Hoshi, and Kashyap, 2006). 
and yet to have resulted in a worse bank health, though the long-run effects of the mergers in the early 2000s may not have been realized yet.

The last column of Table 5A shows the changes of the performance of consolidated banks from the pre-merger acquirer's level for the full sample period. Most of the changes from the pre-merger acquirer's level are qualitatively the same as the changes from the pre-merger hypothetical combined bank, except that the changes in the share of SME loans is not significant, reflecting the fact that the pre-merger acquirer's share of SME loans was higher than the average of major banks.

\section{Regional banks}

Table 5B shows the changes in the financial ratios of the consolidated regional banks. The first column shows the changes from the pre-merger hypothetical combined bank for the full sample period. Like major banks, the changes in ROA are negative, though not significant, three years after mergers and then turn to be positive and significant (for t-statistics) five years after mergers. This increase in ROA is caused partly by a strengthened market power of a consolidated bank in the loan market, which can be seen by the positive and significant change in the loan interest rate three and five years after mergers. Though the increase in the loan interest rate may reflect the change in the riskiness of the portfolio, the share of SME loans, which can be considered to be relatively risky, tended to decrease, if any, rather than to increase after mergers. Furthermore, examining the correlations of the change in the loan interest rate with the 
Herfindahl Index and with the SME loan share, we find that the former is 0.571 , while the latter is 0.243 . A relatively high correlation between the change in the loan interest rate and the Herfindahl Index is consistent with the market power hypothesis. Though there is a possibility that consolidated banks implemented more stringent risk management, it would be difficult to charge higher loan rates without a strengthened market power. The changes in the capital-to-asset ratio are negative up to five years after mergers, though significant only the five-year average after mergers. The improvement of ROA after the merger was too slow and small to offset the initial gap of the capital ratios between consolidated banks and their peers. The advertisement expenses as a proportion of total costs decrease significantly three and five years after mergers, which is not consistent with the managerial empire building hypothesis.

Dividing the sample period into the pre-crisis period and the post-crisis period (the second and third columns, respectively), we see that the changes in the capital-to-asset ratio are negative for both periods but significant only for the post-crisis period, while the change in the fees and commissions is positive and significant in the post-crisis period (for the z-statistics).

The last column shows the changes of the performance of a consolidated bank from the pre-merger acquirer for the full sample period. The changes from the pre-merger acquirer are qualitatively the same as the changes from the pre-merger hypothetical combined bank except for the change in the advertisement expenses from the pre-merger acquirer, which is negative but not significant. 


\section{Shinkin banks}

Table 5C shows the changes in the financial ratios of the consolidated shinkin banks for the full sample period. The first column shows the changes from the hypothetical pre-merger combined bank. Some financial ratios change in similar ways to those of major and regional banks. First, the changes in ROA are negative three years after mergers and then turn to positive, though not significant. Second, the changes in the loan interest rate are positive, though not significant. The correlation of the change in the loan interest with the change in the Herfindahl Index is positive (0.356) and significant, suggesting that the increase in the loan interest rate, if any, may be caused by a strengthened market power. Third, the capital-to-asset ratio and the risk-based capital ratio (BIS) are both negative and significant for most of the post-merger years. Fourth, the changes in the asset growth rate are negative and significant five years after mergers.

The second and third columns show the results for the pre-crisis and post-crisis periods, respectively. The changes in the capita-to-asset ratios and the asset growth rate are negative and significant in both periods, while the change in the risk-based capital ratio is negative in both periods but significant only in the post-crisis period.

The last column shows the changes in the financial ratios of a consolidated bank from the pre-merger acquirer. The changes in the capita-to-asset ratio, the risk-based capital ratio and the asset growth rate are similar to the changes from the hypothetical combined bank, while the changes in the loan growth rates are negative and significant 
up to five years after M\&As and the change in the non-performing loan ratio is positive and significant for the five-year post-merger average.

We may summarize the post-merger performance of consolidated banks as follows. First, consolidated banks tended to go through a decline in ROA at first and then to increase ROA about five years after mergers, though this recovery was significant only for the mergers of regional banks. It seems to take considerable time and costs to integrate different information systems and other business methods. Second, in the case of the M\&As by regional banks or shinkin banks, consolidated banks tended to raise interest rates on loans, though this is significant only for the mergers by regional banks, suggesting that their market power was strengthened within the prefecture they operated in. This is consistent with the U.S. evidence, showing that in-market consolidation strengthens market power. Third, the changes in services provided are different by bank type and by period. Consolidated major banks tended to expand SME loans in the pre-crisis period, while consolidated regional banks tended to expand fees and commissions business in the post-crisis period. Fourth, consolidated banks did not recover bank health after mergers. The capital-to-asset ratio tended to decrease rather than to increase regardless of bank type. The recovery of ROA was too slow and small to fill in the initial gap of the capita-asset-ratio between consolidated banks and their peers. In addition, consolidated banks did not decrease non-performing loans. Finally, consolidated banks tended to decelerate the loan growth rate and the asset growth rate, 
suggesting that consolidated banks tried to restructure assets and to downsize. Consolidated banks did not increase the advertisement expenses. Managerial empire building hypothesis does not seem to be valid in Japan.

\section{Conclusion}

The recent waves of mergers and acquisitions (M\&As) in the banking industries across the world raise important questions of whether mergers enhance the efficiency of consolidated banks and contribute to the stabilization of the banking sector. We investigate the motives and consequences of the consolidation of banks in Japan during the period of fiscal year 1990 to fiscal year 2004. In particular, we test the four hypotheses concerning the motives for bank mergers: efficiency improving, strengthening market power, taking advantage of a too-big-to-fail policy, and managerial empire building.

We first investigated the reasons for the recent merger wave using the aggregate data at the prefecture-level. Our results suggest that M\&As tended to occur when the overall bank health was deteriorated and where the market was less concentrated. These results are consistent with the too-big-to-fail or stabilization policy hypothesis and the market power hypothesis, respectively.

Our analysis concerning the relationship between ex-ante bank characteristics and the decision of M\&As suggests as follows. First, in the post-crisis period (1998-2004), efficient banks tended to acquire an inefficient bank except for the M\&As of corporative 
(shinkin) banks. This finding is consistent with the efficiency-improving hypothesis. Second, unhealthy banks tended to be consolidated with each other especially in the post-crisis period, which is consistent with the too-big-to-fail policy or stabilization policy hypothesis.

Our investigation of post-merger performance suggests as follows. First, consolidated banks tended to go through a decline in ROA at first and then to increase ROA about five years after mergers, though these changes are not necessarily significant. Second, in-market consolidation enabled consolidated banks to raise the loan interest rate. Third, consolidated banks tended to decrease the capital-to-asset ratio and not to decrease non-performing loans. Finally, consolidated banks tended to restrain loan and asset growths and not to increase advertisement expenses.

In sum, our analysis suggests that the government's too-big-to-fail policy or its attempt at stabilizing the local financial market through consolidations played an important role in the M\&As, though its attempt does not seem to have been successful. The efficiency-improving motive also seems to have driven the M\&As conducted by major banks and regional banks in the post-crisis period, while the market-power motive seems to have driven the M\&As conducted by regional banks and corporative (shinkin) banks. We obtain no evidence that supports managerial motives for empire building. 


\section{Data Appendix}

- $R O A=\frac{\text { Current Profit }}{\text { Total Asset }} \times 100$

- Cost Ratio $=\frac{\text { Personnel Expenditure }+ \text { Nonpersonnel Expenditure }+ \text { Taxes }}{\text { Total Asset }} \times 100$

- Fees and Commisions $=\frac{\text { Fees and Commisions }}{\text { Total Asset }} \times 100$

- Loan-to-Asset Ratio $=\frac{\text { Loans Outstanding }}{\text { Total Asset }} \times 100$

- Loans to $S M E s=\frac{\text { Loans to } S M E s}{\text { Total Asset }} \times 100$

- Loan Growth Rate $=$ Growth Rate of Loans Outstanding $\times 100$

- Deposit Interest Rate $=\frac{\text { Interest on Deposits }}{\text { Deposits Outstanding }} \times 100$

- Loan Interest Rate $=\frac{\text { Interest on Loans }}{\text { Loans Outstanding }} \times 100$

- Capital-to-Asset Ratio $=\frac{\text { Equity Capital }}{\text { Total Asset }} \times 100$

- Risk-Based Capital Ratio (BIS) $=\frac{\text { Regulatory Capital }}{\text { Risk Asset }} \times 100$ (Based on BIS)

- Non-Performing Loan Ratio $(B L)=\frac{\text { Non-Performing Loan Based on Banking Law }}{\text { Total Asset }} \times 100$

- Non-Performing Loan Ratio $(F R L)=\frac{\text { Non-Performing Loan Based on Financial Revitalization Law }}{\text { Total Asset }} \times 100$

- Ln Asset = $\ln ($ Total Asset)

- Asset Growth = Growth Rate of Total Asset $\times 100$

- Herfindahl Index = Prefectural Herfindahl Index (calculated by deposits outstanding of regional and shinkin banks)

- GDP Growth = Growth Rate of GDP $\times 100$

- Stock Price = Growth Rate of the Stock Price $\times 100$

- Industrial Stock Price = Growth Rate of the Stock Price Index of banking industry $\times 100$

- Advertisement Expenses $=\frac{\text { Advertisement Expenses }}{\text { Operating Cost }} \times 100$ 
References

Arikawa, Yasuihiro, and Hideaki Miyajima, 2007. Understanding M\&A booms in Japan: What Drives Japanese M\&A? RIETI Discussion Paper 07-E-042.

Berger, Allen N., Rebecca S. Demsetz, and Philip E. Strahan, 1999. The Consolidation of the Financial Services Industry: Cause, Consequences, and Implications for the Future, Journal of Banking and Finance 23, 135-194.

Bliss, Richard T., and Richard J. Rosen, 2001. CEO Compensation and Bank Mergers, Journal of Financial Economics 61, 107-138.

Caballero, Ricardo J., Takeo Hoshi, and Anil A. Kashyap, 2006. Zombie Lending and Depressed Restructuring in Japan, MIT Economics Working Paper No. 06-06.

Delong, Gayle, and Robert Deyoung, 2007. Learning by Observing: Information Spillovers in the Execution and Valuation of Commercial Bank M\&As, Journal of Finance 52(1), 181-216.

Focarelli, Dario, and Fabio Panetta, 2003. Are Mergers Beneficial to Consumers? Evidence from the Market for Bank Deposits, American Economic Review 93, $1152-1172$.

Focarelli, Dario, and Alberto Franco Pozzolo, 2005. Where Do Banks Expand Abroad? An Empirical Analysis. Journal of Business 78, 2435-2463.

Harford, Jarrad, 2005. What Drives Merger waves? Journal of Financial Economics 77, $529-560$.

Hoshi, Takeo, and Anil Kashyap, 2001. Corporate Finance and Governance in Japan: 
The Road to the Future (MIT Press, MA).

Hosono, Kaoru, Koji Sakai, and Kotaro Tsuru, 2006. Consolidation of Corporative Banks (Shinkin) in Japan: Motives and Consequences. RIETI Discussion Paper 06-E-034.

Kano, M., and Y. Tsutsui, 2003. Geographical Segmentation in Japanese Bank Loan Market. Regional Science and Urban Economics 33 (2), 157-174.

Mitchell, Mark L., and J. Harold Mulherin, 1996. The Impact of Industry Shocks on Takeover and Restructuring Activity. Journal of Financial Economics 41(2), 193-229.

Okada, Tae, 2005. Consequences of Bank Mergers [Ginko gappei no kouka, in Japanese], paper presented at the Japanese Economic Association Spring Meeting, 2005.

Peek, Joe, and Eric S. Rosengren, 2005. Unnatural Selection: Perverse Incentives and the Misallocaion of Credit in Japan, American Economic Review 95(4), 1144-1166.

Rhoades, Stephen A., 1998. The Efficiency Effects of Bank Mergers: An Overview of Case Studies of Nine Mergers. Journal of Banking and Finance 22, 273-291.

Shleifer, Andrei, and Robert W. Vishny, 2003. Stock Market Driven Acquisitions. Journal of Financial Economics 70.

Wooldridge, Jefferey M., 2001.Econometric Analysis of Cross Section and Panel Data, MIT Press.

Yafeh, Yishay, and Oved Yosha, 2003. Large Shareholders and Banks: Who Monitors and How? Economic Journal 113 (484), 128-146. 
Yamori, Nobuyoshi, and Kozo Harimaya, 2004. Governance of Shinkin Banks and Choice of Mergers [Shinyou kinko no gabanansu to gappei no sentaku, in Japanese], presented at the symposium on The Governance and Contemporary Meaning of Cooperative Financial Institutions at Hokkaido University.

Yamori, Nobuyoshi, Kozo Harimaya, and K. Kondo, 2005. Are Banks Affiliated with Holding Companies More Efficient than Independent Banks? The Recent Experience regarding Japanese Regional BHCs, Asia Pacific Financial Markets. 
Table 1. Number of Banks and Number of Mergers and Acquisitions (M\&As)

\begin{tabular}{|c|c|c|c|c|c|c|c|c|c|}
\hline & \multicolumn{3}{|c|}{ Major Banks } & \multicolumn{3}{|c|}{ Regional Banks } & \multicolumn{3}{|c|}{ Shinkin Banks } \\
\hline & Total & Merger & $\begin{array}{c}\text { Sale of } \\
\text { business }\end{array}$ & Total & Merger & $\begin{array}{c}\text { Sale of } \\
\text { business }\end{array}$ & Total & Merger & $\begin{array}{c}\text { Sale of } \\
\text { business }\end{array}$ \\
\hline 1990 & 22 & 1 & 0 & 132 & 0 & 0 & 451 & 3 & 0 \\
\hline 1991 & 21 & 1 & 0 & 132 & 1 & 0 & 440 & 3 & 0 \\
\hline 1992 & 21 & 0 & 0 & 130 & 1 & $1(1)$ & 435 & 4 & 0 \\
\hline 1993 & 21 & 0 & 0 & 129 & 1 & 0 & 428 & 5 & 0 \\
\hline 1994 & 21 & 0 & 0 & 129 & 0 & 0 & 421 & 8 & 0 \\
\hline 1995 & 21 & 0 & 0 & 129 & 0 & $1(1)$ & 416 & 4 & 0 \\
\hline 1996 & 20 & 1 & 0 & 128 & 0 & 0 & 410 & 5 & 1 \\
\hline 1997 & 19 & 0 & $1(1)$ & 126 & 0 & $1(1)$ & 401 & 8 & 0 \\
\hline 1998 & 19 & 0 & 0 & 124 & 0 & $3(3)$ & 396 & 3 & 0 \\
\hline 1999 & 19 & 0 & 0 & 123 & 0 & $1(1)$ & 386 & $5(1)$ & $1(1)$ \\
\hline 2000 & 18 & 1 & 0 & 119 & 1 & $1(1)$ & 371 & $7(2)$ & $9(8)$ \\
\hline 2001 & 15 & 3 & 0 & 117 & 0 & 0 & 349 & $11(2)$ & $5(5)$ \\
\hline 2002 & 13 & 3 & 0 & 116 & 0 & 0 & 326 & 15 & $6(6)$ \\
\hline 2003 & 13 & 0 & 0 & 110 & 2 & 0 & 306 & 14 & 0 \\
\hline 2004 & 13 & 0 & 0 & 107 & 3 & 0 & 298 & 7 & 0 \\
\hline Total & 276 & 10 & $1(1)$ & 1,851 & 9 & $8(8)$ & 5,834 & $102(5)$ & $22(20)$ \\
\hline
\end{tabular}

1. Major banks include city banks, long-term credit banks, and trust banks. Regional banks include first-tier regional banks and second-tier regional banks.

2. The numbers in the parentheses denote the numbers of mergers or acquisitions of the business of a failed bank.

3. No merger was implemented across bank type during the sample period, and one sales of business of a failed bank was conducted across bank types (in the case of the failure of a major bank, Hokkaido Takushoku Bank in 1997). 
Table2. Pooled-OLS Regression Results for Merger Wave

\begin{tabular}{|c|c|c|c|}
\hline & \multicolumn{3}{|c|}{ 1985-2004 } \\
\hline & (1) & $(2)$ & (3) \\
\hline ROA & $\begin{array}{l}-0.352 \\
(0.628)\end{array}$ & & \\
\hline Post-Crisis Dummy*ROA & $\begin{array}{l}-0.586 \\
(0.648)\end{array}$ & & \\
\hline Capital-to-Asset Ratio & & $\begin{array}{l}-0.022 \\
(0.070)\end{array}$ & \\
\hline Post-Crisis Dummy*Capital-to-Asset Ratio & & $\begin{array}{l}-0.4500^{* * *} \\
(0.122)\end{array}$ & \\
\hline Industrial Stock Price & & & $\begin{array}{l}-0.0088^{* *} \\
(0.004)\end{array}$ \\
\hline Post-Crisis Dummy*Industrial Stock Price & & & $\begin{array}{c}0.008 \\
(0.015)\end{array}$ \\
\hline Herfindahl Index & $\begin{array}{l}-1.625 * * \\
(0.736)\end{array}$ & $\begin{array}{l}-1.509 \\
(0.740)\end{array}$ & $\begin{array}{l}-2.0777^{* * *} \\
(0.735)\end{array}$ \\
\hline GDP Growth & $\begin{array}{l}-0.099^{* *} \\
(0.040)\end{array}$ & $\begin{array}{l}-0.109^{* * *} \\
(0.040)\end{array}$ & \\
\hline Post-Crisis Dummy & $\begin{array}{l}0.840^{* * *} \\
(0.324)\end{array}$ & $\begin{array}{l}3.2144^{* * *} \\
(0.641)\end{array}$ & $\begin{array}{l}1.377^{* * *} \\
(0.365)^{*}\end{array}$ \\
\hline Cons & $\begin{array}{l}1.665^{* * *} \\
(0.362)\end{array}$ & $\begin{array}{l}1.668^{* * *} \\
(0.453)\end{array}$ & $\begin{array}{l}1.421 \\
(0.313)\end{array}$ \\
\hline Number of Observations & 1,963 & 1,963 & 1,963 \\
\hline Adj R-sq & 0.039 & 0.034 & 0.022 \\
\hline
\end{tabular}

Notes

1. The dependent variable is the numbers of M\&As divided by the total number of banks.

2. Pooled OLS regression results are reported.

3. Standard errors are in parentheses.

4. $* * *$ and $* *$ represent significance at the $1 \%$ and $5 \%$ levels respectively. 
Table 3. Descriptive Sample Statistics

\begin{tabular}{|c|c|c|c|c|c|c|c|c|c|c|c|c|c|c|c|c|}
\hline & \multicolumn{5}{|c|}{ Major Banks } & \multicolumn{5}{|c|}{ Regional Banks } & \multicolumn{6}{|c|}{ Shinkin Banks } \\
\hline & Acquirer & Target & All & $\begin{array}{c}\text { Acquirer } \\
\text {-All }\end{array}$ & $\begin{array}{c}\text { Target- } \\
\text { All }\end{array}$ & Acquirer & Target & All & $\begin{array}{l}\text { Acquirer } \\
\text {-All }\end{array}$ & $\begin{array}{l}\text { Target- } \\
\text { All }\end{array}$ & Acquirer & Target & All & $\begin{array}{c}\text { Acquirer } \\
\text {-All }\end{array}$ & $\begin{array}{c}\text { Target- } \\
\text { All }\end{array}$ & \\
\hline & $\begin{array}{l}\text { Mean } \\
\text { Std. } \\
\text { Dev. }\end{array}$ & $\begin{array}{c}\text { Mean } \\
\text { Std. } \\
\text { Dev. }\end{array}$ & $\begin{array}{c}\text { Mean } \\
\text { Std. } \\
\text { Dev. }\end{array}$ & $\begin{array}{c}\text { Mean } \\
\text { Std. } \\
\text { Dev. }\end{array}$ & $\begin{array}{c}\text { Mean } \\
\text { Std. } \\
\text { Dev. }\end{array}$ & $\begin{array}{c}\text { Mean } \\
\text { Std. } \\
\text { Dev. }\end{array}$ & $\begin{array}{c}\text { Mean } \\
\text { Std. } \\
\text { Dev. }\end{array}$ & $\begin{array}{c}\text { Mean } \\
\text { Std. } \\
\text { Dev. }\end{array}$ & $\begin{array}{l}\text { Mean } \\
\text { Std. } \\
\text { Dev. }\end{array}$ & $\begin{array}{c}\text { Mean } \\
\text { Std. } \\
\text { Dev. }\end{array}$ & $\begin{array}{c}\text { Mean } \\
\text { Std. } \\
\text { Dev. }\end{array}$ & $\begin{array}{c}\text { Mean } \\
\text { Std. } \\
\text { Dev. }\end{array}$ & $\begin{array}{c}\text { Mean } \\
\text { Std. } \\
\text { Dev. }\end{array}$ & $\begin{array}{l}\text { Mean } \\
\text { Std. } \\
\text { Dev. }\end{array}$ & $\begin{array}{c}\text { Mean } \\
\text { Std. } \\
\text { Dev. }\end{array}$ & \\
\hline$R O A$ & $\begin{array}{l}-0.32 \\
(1.08)\end{array}$ & $\begin{array}{l}-0.36 \\
(0.79)\end{array}$ & $\begin{array}{l}-0.27 \\
(1.13)\end{array}$ & $\begin{array}{l}-0.19 \\
(0.85)\end{array}$ & $\begin{array}{c}0.00 \\
(0.65)\end{array}$ & $\begin{array}{c}0.13 \\
(0.37)\end{array}$ & $\begin{array}{l}-0.06 \\
(0.49)\end{array}$ & $\begin{array}{l}-0.17 \\
(2.16)\end{array}$ & $\begin{array}{c}0.23 \\
(0.31)\end{array}$ & $\begin{array}{c}0.06 \\
(0.17)\end{array}$ & $\begin{array}{c}0.11 \\
(0.47)\end{array}$ & $\begin{array}{l}-0.27 \\
(0.96)\end{array}$ & $\begin{array}{c}0.19 \\
(1.03)\end{array}$ & $\begin{array}{l}-0.01 \\
(0.44)\end{array}$ & $\begin{array}{l}-0.37 \\
(0.89)\end{array}$ & \\
\hline Cost Ratio & $\begin{array}{c}0.85 \\
(0.35)\end{array}$ & $\begin{array}{c}0.95 \\
(0.66)\end{array}$ & $\begin{array}{c}0.86 \\
(0.41)\end{array}$ & $\begin{array}{c}0.01 \\
(0.32)\end{array}$ & $\begin{array}{c}0.12 \\
(0.64)\end{array}$ & $\begin{array}{c}1.43 \\
(0.25)\end{array}$ & $\begin{array}{c}1.48 \\
(0.17)\end{array}$ & $\begin{array}{l}1.45 \\
(0.26)\end{array}$ & $\begin{array}{c}0.03 \\
(0.22)\end{array}$ & $\begin{array}{c}0.07 \\
(0.16)\end{array}$ & $\begin{array}{l}1.61 \\
(0.20)\end{array}$ & $\begin{array}{r}1.69 \\
(0.36)\end{array}$ & $\begin{array}{c}1.64 \\
(0.24)\end{array}$ & $\begin{array}{l}-0.01 \\
(0.20)\end{array}$ & $\begin{array}{c}0.07 \\
(0.36)\end{array}$ & \\
\hline Fees and Commissions & $\begin{array}{c}0.26 \\
(0.13)\end{array}$ & $\begin{array}{c}0.29 \\
(0.26)\end{array}$ & $\begin{array}{c}0.26 \\
(0.16)\end{array}$ & $\begin{array}{l}-0.01 \\
(0.13)\end{array}$ & $\begin{array}{c}0.01 \\
(0.26)\end{array}$ & $\begin{array}{c}0.25 \\
(0.10)\end{array}$ & $\begin{array}{c}0.20 \\
(0.10)\end{array}$ & $\begin{array}{c}0.19 \\
(0.06)\end{array}$ & $\begin{array}{c}0.03 \\
(0.08)\end{array}$ & $\begin{array}{l}-0.02 \\
(0.07)\end{array}$ & $\begin{array}{c}0.16 \\
(0.04)\end{array}$ & $\begin{array}{c}0.15 \\
(0.04)\end{array}$ & $\begin{array}{c}0.15 \\
(0.04)\end{array}$ & $\begin{array}{c}0.00 \\
(0.04)\end{array}$ & $\begin{array}{c}0.00 \\
(0.04)\end{array}$ & \\
\hline Loan-to-Asset Ratio & $\begin{array}{l}56.60 \\
(6.50)\end{array}$ & $\begin{array}{l}57.83 \\
(6.62)\end{array}$ & $\begin{array}{l}56.12 \\
(8.81)\end{array}$ & $\begin{array}{c}1.38 \\
(7.53)\end{array}$ & $\begin{array}{c}2.29 \\
(8.57)\end{array}$ & $\begin{array}{l}70.85 \\
(5.28)\end{array}$ & $\begin{array}{l}71.82 \\
(4.43)\end{array}$ & $\begin{array}{l}69.33 \\
(7.03)\end{array}$ & $\begin{array}{c}2.44 \\
(5.15)\end{array}$ & $\begin{array}{c}3.36 \\
(4.93)\end{array}$ & $\begin{array}{l}61.29 \\
(6.95)\end{array}$ & $\begin{array}{c}57.77 \\
(10.26)\end{array}$ & $\begin{array}{l}58.84 \\
(8.53)\end{array}$ & $\begin{array}{l}3.17^{* * *} \\
(6.55)^{*}\end{array}$ & $\begin{array}{c}-0.19 \\
(10.27)\end{array}$ & \\
\hline Loans to SMEs & $\begin{array}{l}28.53 \\
(7.68)\end{array}$ & $\begin{array}{l}24.22 \\
(6.12)\end{array}$ & $\begin{array}{l}27.84 \\
(7.75)\end{array}$ & $\begin{array}{c}2.07 \\
(6.84)\end{array}$ & $\begin{array}{l}-1.89 \\
(7.49)\end{array}$ & $\begin{array}{l}47.98 \\
(8.11)\end{array}$ & $\begin{array}{l}52.13 \\
(6.43)\end{array}$ & $\begin{array}{l}47.96 \\
(9.52)\end{array}$ & $\begin{array}{c}2.73 \\
(7.24)\end{array}$ & $\begin{array}{c}6.34 \\
(7.75)\end{array}$ & & & & & & \\
\hline Loan Growth Rate & $\begin{array}{c}5.99 \\
(10.03)\end{array}$ & $\begin{array}{c}0.08 \\
(9.31)\end{array}$ & $\begin{array}{c}2.32 \\
(18.58)\end{array}$ & $\begin{array}{c}0.11 \\
(12.39)\end{array}$ & $\begin{array}{l}-5.34 \\
(8.97)\end{array}$ & $\begin{array}{c}9.48 \\
(23.32)\end{array}$ & $\begin{array}{l}-0.41 \\
(5.33)\end{array}$ & $\begin{array}{c}2.81 \\
(8.01)\end{array}$ & $\begin{array}{c}7.57 \\
(23.15)\end{array}$ & $\begin{array}{l}-2.36 \\
(3.91)\end{array}$ & $\begin{array}{c}2.12 \\
(5.72)\end{array}$ & $\begin{array}{l}-2.35 \\
(5.78)\end{array}$ & $\begin{array}{c}4.09 \\
(8.72)\end{array}$ & $\begin{array}{l}-0.38 \\
(3.93)\end{array}$ & $\begin{array}{l}-4.46 \\
(4.86)\end{array}$ & *** \\
\hline Deposit Interest Rate & $\begin{array}{c}2.29 \\
(2.08)\end{array}$ & $\begin{array}{c}1.87 \\
(2.01)\end{array}$ & $\begin{array}{c}3.04 \\
(2.26)\end{array}$ & $\begin{array}{l}-0.23 \\
(0.54)\end{array}$ & $\begin{array}{l}-0.13 \\
(0.92)\end{array}$ & $\begin{array}{c}1.49 \\
(2.08)\end{array}$ & $\begin{array}{c}1.79 \\
(2.28)\end{array}$ & $\begin{array}{c}1.75 \\
(1.67)\end{array}$ & $\begin{array}{l}-0.06 \\
(0.11)\end{array}$ & $\begin{array}{c}0.07 \\
(0.23)\end{array}$ & $\begin{array}{c}1.39 \\
(1.47)\end{array}$ & $\begin{array}{c}1.25 \\
(1.47)\end{array}$ & $\begin{array}{c}1.91 \\
(1.57)\end{array}$ & $\begin{array}{c}0.00 \\
(0.18)\end{array}$ & $\begin{array}{c}0.02 \\
(0.13)\end{array}$ & \\
\hline Loan Interest Rate & $\begin{array}{c}3.47 \\
(2.19)\end{array}$ & $\begin{array}{c}3.14 \\
(1.87)\end{array}$ & $\begin{array}{r}3.96 \\
(2.06)\end{array}$ & $\begin{array}{l}-0.06 \\
(0.27)\end{array}$ & $\begin{array}{c}0.03 \\
(0.42)\end{array}$ & $\begin{array}{c}3.85 \\
(2.22)\end{array}$ & $\begin{array}{c}4.51 \\
(2.16)\end{array}$ & $\begin{array}{c}4.05 \\
(1.76)\end{array}$ & $\begin{array}{l}-0.04 \\
(0.38)\end{array}$ & $\begin{array}{l}0.43^{* * *} \\
(0.24)\end{array}$ & $\begin{array}{c}4.24 \\
(1.57)\end{array}$ & $\begin{array}{c}4.08 \\
(1.60)\end{array}$ & $\begin{array}{c}4.78 \\
(1.64)\end{array}$ & $\begin{array}{c}0.01 \\
(0.34)\end{array}$ & $\begin{array}{c}0.02 \\
(0.49)\end{array}$ & \\
\hline Capital-to-Asset Ratio & $\begin{array}{c}3.75 \\
(1.37)\end{array}$ & $\begin{array}{c}4.02 \\
(1.57)\end{array}$ & $\begin{array}{c}3.95 \\
(1.47)\end{array}$ & $\begin{array}{l}-0.46 \\
(1.02)\end{array}$ & $\begin{array}{l}-0.19 \\
(1.19)\end{array}$ & $\begin{array}{c}3.27 \\
(0.68)\end{array}$ & $\begin{array}{c}3.11 \\
(1.36)\end{array}$ & $\begin{array}{c}3.67 \\
(3.19)\end{array}$ & $\begin{array}{l}-0.73 \\
(0.96)\end{array}$ & $\begin{array}{l}-0.81 \\
(1.09)\end{array}$ & $\begin{array}{c}4.92 \\
(1.44)\end{array}$ & $\begin{array}{c}4.11 \\
(1.99)\end{array}$ & $\begin{array}{c}5.34 \\
(2.16)\end{array}$ & $\begin{array}{l}-0.51^{* * *} \\
(1.45)^{*}\end{array}$ & $\begin{array}{l}-1.34 \\
(2.03)\end{array}$ & *** \\
\hline Risk-Based Capital Ratio (BIS) & $\begin{array}{l}10.31 \\
(1.70)\end{array}$ & $\begin{array}{l}10.55 \\
(1.55)\end{array}$ & $\begin{array}{l}11.50 \\
(2.58)\end{array}$ & $\begin{array}{l}-1.36 \\
(1.37)\end{array}$ & $\begin{array}{l}-0.89 \\
(1.54)\end{array}$ & $\begin{array}{c}7.30 \\
(1.31)\end{array}$ & $\begin{array}{c}6.15 \\
(1.70)\end{array}$ & $\begin{array}{c}8.77 \\
(3.80)\end{array}$ & $\begin{array}{l}-1.722^{* *} \\
(1.27)\end{array}$ & $\begin{array}{l}-2.86 \\
(1.76)\end{array}$ & $\begin{array}{c}8.86 \\
(3.15)\end{array}$ & $\begin{array}{c}7.18 \\
(3.44)\end{array}$ & $\begin{array}{c}9.65 \\
(4.11)\end{array}$ & $\begin{array}{l}-1.12^{* *} \\
(2.87)\end{array}$ & $\begin{array}{l}-2.98 \\
(3.45)\end{array}$ & *** \\
\hline Non-Performing Loan Ratio (BL) & $\begin{array}{c}8.72 \\
(4.46)\end{array}$ & $\begin{array}{c}8.99 \\
(6.72)\end{array}$ & $\begin{array}{l}10.32 \\
(7.87)\end{array}$ & $\begin{array}{l}-1.46 \\
(3.66)\end{array}$ & $\begin{array}{l}-1.74 \\
(7.13)\end{array}$ & $\begin{array}{c}9.40 \\
(3.03)\end{array}$ & $\begin{array}{c}9.59 \\
(2.62)\end{array}$ & $\begin{array}{c}7.15 \\
(5.15)\end{array}$ & $\begin{array}{c}1.56 \\
(2.63)\end{array}$ & $\begin{array}{c}1.74 \\
(2.06)\end{array}$ & $\begin{array}{c}9.69 \\
(6.42)\end{array}$ & $\begin{array}{l}14.15 \\
(6.69)\end{array}$ & $\begin{array}{c}7.81 \\
(5.75)\end{array}$ & $\begin{array}{c}0.50 \\
(4.98)\end{array}$ & $\begin{array}{c}4.67 \\
(6.05)\end{array}$ & *** \\
\hline Non-Performing Loan Ratio (FRL) & $\begin{array}{c}8.92 \\
(4.53)\end{array}$ & $\begin{array}{c}9.17 \\
(6.80)\end{array}$ & $\begin{array}{c}9.77 \\
(6.79)\end{array}$ & $\begin{array}{l}-1.40 \\
(3.71)\end{array}$ & $\begin{array}{l}-1.75 \\
(7.25)\end{array}$ & $\begin{array}{c}9.48 \\
(3.19)\end{array}$ & $\begin{array}{l}10.33 \\
(3.56)\end{array}$ & $\begin{array}{c}8.01 \\
(4.93)\end{array}$ & $\begin{array}{c}1.71 \\
(2.98)\end{array}$ & $\begin{array}{c}2.40 \\
(2.95)\end{array}$ & & & & & & \\
\hline Advertisement Expenses & $\begin{array}{c}1.76 \\
(0.93)\end{array}$ & $\begin{array}{c}1.47 \\
(0.77)\end{array}$ & $\begin{array}{c}1.91 \\
(1.07)\end{array}$ & $\begin{array}{c}0.00 \\
(1.02)\end{array}$ & $\begin{array}{l}-0.19 \\
(0.76)\end{array}$ & $\begin{array}{c}1.68 \\
(0.90)\end{array}$ & $\begin{array}{r}1.99 \\
(0.94)\end{array}$ & $\begin{array}{l}1.60 \\
(0.65)\end{array}$ & $\begin{array}{c}0.21 \\
(0.90)\end{array}$ & $\begin{array}{c}0.50 \\
(1.00)\end{array}$ & & & & & & \\
\hline Stock Price & $\begin{array}{l}-17.58 \\
(16.15)\end{array}$ & $\begin{array}{l}-22.60 \\
(10.61)\end{array}$ & $\begin{array}{l}-10.77 \\
(28.79)\end{array}$ & $\begin{array}{c}-4.28 \\
(15.49)\end{array}$ & $\begin{array}{c}6.83 \\
(10.61)\end{array}$ & & & & & & & & & & & \\
\hline Ln Asset & $\begin{array}{l}17.03 \\
(0.84)\end{array}$ & $\begin{array}{l}16.87 \\
(1.15)\end{array}$ & $\begin{array}{l}16.85 \\
(0.96)\end{array}$ & $\begin{array}{c}0.18 \\
(0.82)\end{array}$ & $\begin{array}{c}0.00 \\
(1.13)\end{array}$ & $\begin{array}{l}14.27 \\
(0.56)\end{array}$ & $\begin{array}{l}13.67 \\
(0.74)\end{array}$ & $\begin{array}{l}14.19 \\
(0.89)\end{array}$ & $\begin{array}{c}0.04 \\
(0.54)\end{array}$ & $\begin{array}{l}-0.54 \\
(0.71)\end{array}$ & $\begin{array}{l}19.38 \\
(0.86)\end{array}$ & $\begin{array}{l}18.20 \\
(0.93)\end{array}$ & $\begin{array}{l}18.82 \\
(0.97)\end{array}$ & $\begin{array}{l}0.49^{* * *} \\
(0.84)\end{array}$ & $\begin{array}{l}-0.70 \\
(0.89)\end{array}$ & *** \\
\hline Asset Growth Rate & $\begin{array}{c}9.57 \\
(10.63)\end{array}$ & $\begin{array}{c}-0.60 \\
(10.63)\end{array}$ & $\begin{array}{c}1.35 \\
(17.57)\end{array}$ & $\begin{array}{c}3.02 \\
(6.86)\end{array}$ & $\begin{array}{l}-5.32 \\
(9.80)\end{array}$ & $\begin{array}{c}9.17 \\
(21.63)\end{array}$ & $\begin{array}{c}1.99 \\
(4.55)\end{array}$ & $\begin{array}{c}2.30 \\
(8.82)\end{array}$ & $\begin{array}{c}7.71 \\
(21.21)\end{array}$ & $\begin{array}{c}0.64 \\
(4.84)\end{array}$ & $\begin{array}{c}2.63 \\
(4.37)\end{array}$ & $\begin{array}{l}-0.68 \\
(8.88)\end{array}$ & $\begin{array}{c}4.06 \\
(8.17)\end{array}$ & $\begin{array}{l}-0.62 \\
(3.32)\end{array}$ & $\begin{array}{l}-3.84 \\
(8.35)\end{array}$ & $* * *$ \\
\hline Number of Observations & 8 & 11 & 286 & & & 9 & 8 & 1,876 & & & 64 & 80 & 5,928 & & & \\
\hline
\end{tabular}

Notes

1. $\quad * * *$ and $* *$ denote significance at the $1 \%$ and $5 \%$ levels respectively, for the null hypothesis that the difference has zero mean. 
2. "Acquirer-All" and "Target-All" are calculated for each M\&A and only for the years when there are at least one M\&A, while "All" is a simple average over the whole sample years. This is the reason why the differences between "Acquirer" (or "Target") and "All” do not coincide with "Acquirer-All" (or "Target-All"). 
Table 4A. Multinomial Logistic Regression Results for M\&A Choices among Major Banks

\begin{tabular}{|c|c|c|c|c|c|c|c|c|c|c|c|c|c|c|}
\hline & \multicolumn{6}{|c|}{$1990-2004$} & \multicolumn{2}{|c|}{$1990-2001$} & \multicolumn{2}{|c|}{$1990-2004$} & \multicolumn{2}{|c|}{$1990-1997$} & \multicolumn{2}{|c|}{$1998-2004$} \\
\hline & Coeff. & $\begin{array}{l}\text { Marg. } \\
\text { Eff. }\end{array}$ & Coeff. & $\begin{array}{c}\text { Marg. } \\
\text { Eff. }\end{array}$ & Coeff. & $\begin{array}{l}\text { Marg. } \\
\text { Eff. }\end{array}$ & Coeff. & $\begin{array}{c}\text { Marg. } \\
\text { Eff. }\end{array}$ & Coeff. & $\begin{array}{c}\text { Marg. } \\
\text { Eff. }\end{array}$ & Coeff. & $\begin{array}{c}\text { Marg. } \\
\text { Eff. }\end{array}$ & Coeff. & $\begin{array}{c}\text { Marg. } \\
\text { Eff. }\end{array}$ \\
\hline & (1) & $(2)$ & (3) & (4) & (5) & (6) & (7) & $(8)$ & (9) & $(10)$ & (11) & $(12)$ & (13) & (14) \\
\hline \multicolumn{15}{|l|}{ Acquirer } \\
\hline$R O A$ & $\begin{array}{r}-0.200 \\
(0.470)\end{array}$ & -0.0000 & $\begin{array}{r}-0.267 \\
(0.342)\end{array}$ & -0.0000 & & & & & $\begin{array}{r}0.284 \\
(0.843)\end{array}$ & 0.0000 & $\begin{array}{r}17.817 \\
(19.158)\end{array}$ & 0.0000 & $\begin{array}{r}0.079 \\
(0.900)\end{array}$ & 0.0001 \\
\hline Cost Ratio & $\begin{array}{r}3.157 \\
(2.207)\end{array}$ & 0.0028 & $\begin{array}{r}2.451 \\
(2.073)\end{array}$ & 0.0000 & $\begin{array}{r}3.138 \\
(2.201)\end{array}$ & 0.0000 & $\begin{array}{r}0.433 \\
(2.475)\end{array}$ & -0.0046 & $\begin{array}{r}1.734 \\
(2.065)\end{array}$ & 0.0020 & $\begin{array}{r}1.907 \\
(4.665)\end{array}$ & 0.0000 & $\begin{array}{r}5.054 \\
(2.820)\end{array}$ & 0.0155 \\
\hline Capital-to-Asset Ratio & $\begin{array}{r}-0.421 \\
(0.426)\end{array}$ & -0.0003 & & & $\begin{array}{r}-0.478 \\
(0.416)\end{array}$ & -0.0000 & & & $\begin{array}{r}0.313 \\
(0.369)\end{array}$ & 0.0004 & $\begin{array}{r}-4.355 \\
(3.079)\end{array}$ & -0.0727 & $\begin{array}{r}-0.954 \\
(0.716)\end{array}$ & -0.0323 \\
\hline Advertisement Expenses & $\begin{array}{r}0.218 \\
(0.497)\end{array}$ & 0.0000 & $\begin{array}{r}0.129 \\
(0.500)\end{array}$ & 0.0000 & $\begin{array}{r}0.195 \\
(0.499)\end{array}$ & 0.0000 & $\begin{array}{r}0.092 \\
(0.524)\end{array}$ & 0.0052 & $\begin{array}{l}-0.275 \\
(0.539)\end{array}$ & -0.0000 & $\begin{array}{r}-0.505 \\
(0.880)\end{array}$ & -0.0000 & $\begin{array}{r}2.062 \\
(1.179)\end{array}$ & 0.0030 \\
\hline Ln Asset & $\begin{array}{r}1.255 \\
(0.936)\end{array}$ & 0.0437 & $\begin{array}{r}1.284 \\
(0.918)\end{array}$ & 0.0437 & $\begin{array}{r}1.178 \\
(0.916)\end{array}$ & 0.0072 & $\begin{array}{r}0.766 \\
(1.025)\end{array}$ & 0.0043 & $\begin{array}{r}0.937 \\
(0.909)\end{array}$ & 0.0026 & $\begin{array}{r}-0.200 \\
(1.561)\end{array}$ & 0.0024 & $\begin{array}{r}2.015 \\
(1.607)\end{array}$ & 0.0641 \\
\hline Asset Growth & $\begin{array}{r}0.017 \\
(0.018)\end{array}$ & 0.0000 & $\begin{array}{r}0.018 \\
(0.017)\end{array}$ & 0.0000 & $\begin{array}{r}0.017 \\
(0.018)\end{array}$ & 0.0000 & $\begin{array}{r}0.024 \\
(0.017)\end{array}$ & 0.0000 & $\begin{array}{r}0.019 \\
(0.017)\end{array}$ & 0.0000 & $\begin{array}{r}-0.001 \\
(0.044)\end{array}$ & -0.0000 & $\begin{array}{r}0.011 \\
(0.021)\end{array}$ & 0.0000 \\
\hline Industrial Stock Price & $\begin{array}{r}-0.031 \\
(0.033)\end{array}$ & -0.0000 & $\begin{array}{r}-0.038 \\
(0.033)\end{array}$ & -0.0000 & $\begin{array}{r}-0.028 \\
(0.032)\end{array}$ & -0.0000 & & & $\begin{array}{r}0.019 \\
(0.031)\end{array}$ & 0.0000 & $\begin{array}{r}0.747 \\
(0.595)\end{array}$ & 0.0000 & $\begin{array}{r}-0.150 \\
(0.096)\end{array}$ & -0.0018 \\
\hline GDP Growth & $\begin{array}{r}0.527 \\
(0.279)\end{array}$ & 0.0000 & $\begin{array}{r}0.455 \\
(0.266)\end{array}$ & 0.0000 & $\begin{array}{r}0.508 \\
(0.274)\end{array}$ & 0.0000 & & & $\begin{array}{r}0.578 \\
(0.324)\end{array}$ & 0.0000 & $\begin{array}{r}5.310 \\
(4.326)\end{array}$ & -0.0011 & $\begin{array}{r}0.189 \\
(0.793)\end{array}$ & 0.0002 \\
\hline M\&A Experience & $\begin{array}{r}-2.783 \\
(1.600)\end{array}$ & -0.0506 & $\begin{array}{r}-2.402 \\
(1.479)\end{array}$ & -0.0435 & $\begin{array}{r}-2.729 \\
(1.589)\end{array}$ & -0.0499 & $\begin{array}{r}-1.768 \\
(1.537)\end{array}$ & -0.0311 & $\begin{array}{r}-1.941 \\
(1.390)\end{array}$ & -0.0345 & & & $\begin{array}{r}-3.447 \\
(1.977)\end{array}$ & -0.1163 \\
\hline Governmental Capital & $\begin{array}{r}2.9877^{* *} \\
(1.338)\end{array}$ & 0.1209 & $\begin{array}{l}2.2477^{* *} \\
(1.024)\end{array}$ & 0.0745 & $\begin{array}{c}3.0766^{* *} \\
(1.349)\end{array}$ & 0.1271 & $\begin{array}{r}1.685 \\
(0.894)\end{array}$ & 0.0650 & $\begin{array}{r}2.617 \\
(1.353)\end{array}$ & 0.1054 & & & & \\
\hline Stock Price & & & & & & & $\begin{array}{r}-0.005 \\
(0.016)\end{array}$ & -0.0000 & & & & & & \\
\hline Non-performing Loan Ratio & & & & & & & & & & & & & $\begin{array}{r}-0.019 \\
(0.269)\end{array}$ & 0.0024 \\
\hline Cons & $\begin{array}{r}-28.848 \\
(18.148) \\
\end{array}$ & & $\begin{array}{r}-29.828 \\
(17.845) \\
\end{array}$ & & $\begin{array}{r}-27.195 \\
(17.645) \\
\end{array}$ & & $\begin{array}{r}-17.567 \\
(19.683) \\
\end{array}$ & & $\begin{array}{r}-23.765 \\
(17.740) \\
\end{array}$ & & $\begin{array}{r}-5.595 \\
(30.763) \\
\end{array}$ & & $\begin{array}{r}-42.340 \\
(31.100) \\
\end{array}$ & \\
\hline
\end{tabular}


Table 4A. (Continued from previous page)

\begin{tabular}{|c|c|c|c|c|c|c|c|c|c|c|c|c|c|c|}
\hline & \multicolumn{6}{|c|}{$1990-2004$} & \multicolumn{2}{|c|}{ 1990-2001 } & \multicolumn{2}{|c|}{ 1990-2004 } & \multicolumn{2}{|c|}{ 1990-1997 } & \multicolumn{2}{|c|}{ 1998-2004 } \\
\hline & Coeff. & $\begin{array}{l}\text { Marg. } \\
\text { Eff. }\end{array}$ & Coeff. & $\begin{array}{l}\text { Marg. } \\
\text { Eff. }\end{array}$ & Coeff. & $\begin{array}{l}\text { Marg. } \\
\text { Eff. }\end{array}$ & Coeff. & $\begin{array}{c}\text { Marg. } \\
\text { Eff. }\end{array}$ & Coeff. & $\begin{array}{c}\text { Marg. } \\
\text { Eff. }\end{array}$ & Coeff. & $\begin{array}{l}\text { Marg. } \\
\text { Eff. }\end{array}$ & Coeff. & $\begin{array}{c}\text { Marg. } \\
\text { Eff. }\end{array}$ \\
\hline & (1) & (2) & (3) & (4) & (5) & (6) & (7) & (8) & (9) & (10) & (11) & (12) & (13) & (14) \\
\hline \multicolumn{15}{|l|}{ Target } \\
\hline$R O A$ & $\begin{array}{l}-0.082 \\
(0.401)\end{array}$ & -0.0000 & $\begin{array}{l}-0.092 \\
(0.366)\end{array}$ & -0.0000 & & & & & $\begin{array}{c}0.001 \\
(0.284)\end{array}$ & 0.0000 & $\begin{array}{c}7.495 \\
(9.127)\end{array}$ & 0.0000 & $\begin{array}{c}0.323 \\
(0.915)\end{array}$ & -0.0001 \\
\hline Cost Ratio & $\begin{array}{c}2.134 \\
(1.637)\end{array}$ & 0.0010 & $\begin{array}{c}2.110 \\
(1.626)\end{array}$ & 0.0000 & $\begin{array}{c}2.119 \\
(1.629)\end{array}$ & 0.0000 & $\begin{array}{c}6.011 \\
(4.998)\end{array}$ & 0.0574 & $\begin{array}{c}1.821 \\
(1.640)\end{array}$ & 0.0039 & $\begin{array}{l}-1.494 \\
(3.793)\end{array}$ & -0.0000 & $\begin{array}{l}7.4844^{* *} \\
(3.292)\end{array}$ & 0.3149 \\
\hline Capital-to-Asset Ratio & $\begin{array}{l}-0.051 \\
(0.355)\end{array}$ & 0.0001 & & & $\begin{array}{l}-0.075 \\
(0.334)\end{array}$ & 0.0000 & & & $\begin{array}{l}0.613 \\
(0.305)\end{array}$ & 0.0090 & $\begin{array}{l}-2.184 \\
(1.778)\end{array}$ & -0.0272 & $\begin{array}{c}0.209 \\
(0.702)\end{array}$ & 0.0153 \\
\hline Advertisement Expenses & $\begin{array}{l}-0.286 \\
(0.519)\end{array}$ & -0.0000 & $\begin{array}{l}-0.294 \\
(0.516)\end{array}$ & -0.0000 & $\begin{array}{l}-0.297 \\
(0.515)\end{array}$ & -0.0000 & $\begin{array}{r}-11.020 \\
(6.692)\end{array}$ & -0.0692 & $\begin{array}{l}-0.645 \\
(0.527)\end{array}$ & -0.0000 & $\begin{array}{l}-0.545 \\
(0.641)\end{array}$ & -0.0000 & $\begin{array}{c}0.344 \\
(0.970)\end{array}$ & -0.0024 \\
\hline Ln Asset & $\begin{array}{c}0.868 \\
(0.792)\end{array}$ & 0.0082 & $\begin{array}{c}0.895 \\
(0.762)\end{array}$ & 0.0103 & $\begin{array}{c}0.832 \\
(0.769)\end{array}$ & 0.0116 & $\begin{array}{c}3.524 \\
(3.155)\end{array}$ & 0.0282 & $\begin{array}{c}1.195 \\
(0.789)\end{array}$ & 0.0596 & $\begin{array}{l}-1.689 \\
(1.586)\end{array}$ & -0.0288 & $\begin{array}{c}1.513 \\
(1.718)\end{array}$ & 0.0518 \\
\hline Asset Growth & $\begin{array}{l}-0.028 \\
(0.032)\end{array}$ & -0.0000 & $\begin{array}{l}-0.028 \\
(0.031)\end{array}$ & -0.0000 & $\begin{array}{l}-0.029 \\
(0.032)\end{array}$ & -0.0000 & $\begin{array}{c}0.094 \\
(0.071)\end{array}$ & 0.0000 & $\begin{array}{c}0.001 \\
(0.022)\end{array}$ & 0.0000 & $\begin{array}{c}0.018 \\
(0.054)\end{array}$ & 0.0000 & $\begin{array}{l}-0.055 \\
(0.064)\end{array}$ & -0.0000 \\
\hline Industrial Stock Price & $\begin{array}{l}-0.0833^{* *} \\
(0.042)\end{array}$ & 0.0000 & $\begin{array}{l}-0.084 \text { ** } \\
(0.042)\end{array}$ & -0.0000 & $\begin{array}{l}-0.083 \\
(0.042)\end{array}$ & -0.0000 & & & $\begin{array}{l}-0.021 \\
(0.027)\end{array}$ & -0.0000 & $\begin{array}{c}0.458 \\
(0.383)\end{array}$ & 0.0000 & $\begin{array}{l}-0.427 \\
(0.315)\end{array}$ & -0.0203 \\
\hline GDP Growth & $\begin{array}{c}0.499 \\
(0.282)\end{array}$ & 0.0000 & $\begin{array}{c}0.493 \\
(0.277)\end{array}$ & 0.0000 & $\begin{array}{c}0.495 \\
(0.284)\end{array}$ & 0.0000 & & & $\begin{array}{c}0.351 \\
(0.242)\end{array}$ & 0.0000 & $\begin{array}{c}3.305 \\
(2.837)\end{array}$ & 0.0064 & $\begin{array}{c}1.204 \\
(1.870)\end{array}$ & 0.0039 \\
\hline M\&A Experience & $\begin{array}{l}-1.164 \\
(0.972)\end{array}$ & -0.0290 & $\begin{array}{l}-1.146 \\
(0.965)\end{array}$ & -0.0292 & $\begin{array}{l}-1.142 \\
(0.967)\end{array}$ & -0.0287 & $\begin{array}{l}-2.962 \\
(3.029)\end{array}$ & -0.0275 & $\begin{array}{l}-1.283 \\
(0.978)\end{array}$ & -0.0337 & & & $\begin{array}{l}-1.744 \\
(1.359)\end{array}$ & -0.0495 \\
\hline Governmental Capital & $\begin{array}{c}1.792 \\
(1.010)\end{array}$ & 0.0576 & $\begin{array}{l}1.721{ }^{* *} \\
(0.844)\end{array}$ & 0.0610 & $\begin{array}{c}1.838 \\
(0.986)\end{array}$ & 0.0586 & $\begin{array}{c}2.525 \\
(3.004)\end{array}$ & 0.0178 & $\begin{array}{c}1.011 \\
(0.930)\end{array}$ & 0.0281 & & & & \\
\hline Stock Price & & & & & & & $\begin{array}{l}-0.035 \\
(0.055)\end{array}$ & -0.0000 & & & & & & \\
\hline Non-performing Loan Ratio & & & & & & & & & & & & & $\begin{array}{l}-0.399 \\
(0.281)\end{array}$ & -0.0090 \\
\hline Cons & $\begin{array}{l}-21.920 \\
(15.593)\end{array}$ & & $\begin{array}{l}-22.526 \\
(14.882)\end{array}$ & & $\begin{array}{l}-21.181 \\
(15.110)\end{array}$ & & $\begin{array}{l}-60.254 \\
(54.140)\end{array}$ & & $\begin{array}{l}-27.602 \\
(15.501)\end{array}$ & & $\begin{array}{c}23.337 \\
(29.490)\end{array}$ & & $\begin{array}{l}-42.943 \\
(34.366)\end{array}$ & \\
\hline Number of Observations & 279 & & 280 & & 279 & & 225 & & 279 & & 170 & & 90 & \\
\hline Pseudo R-sq & 0.168 & & 0.162 & & 0.167 & & 0.272 & & 0.166 & & 0.277 & & 0.446 & \\
\hline Log Likelihood & -68.457 & & -69.027 & & -68.547 & & -34.234 & & -68.641 & & -21.780 & & -25.370 & \\
\hline
\end{tabular}

Notes

1. The probability of being an acquirer or a target as compared with being neither of them is estimated using the maximum-likelihood estimator

2. Standard errors are in parentheses.

3. $* * *$ and $* *$ represent significance at the $1 \%$ and $5 \%$ levels, respectively

4. Independent variables are lagged one year for columns (1)-(8) and (11)-(14), while they are lagged two years for columns (9) and (10) 
Table 4B. Multinomial Logistic Regression Results for M\&A Choices among Regional Banks

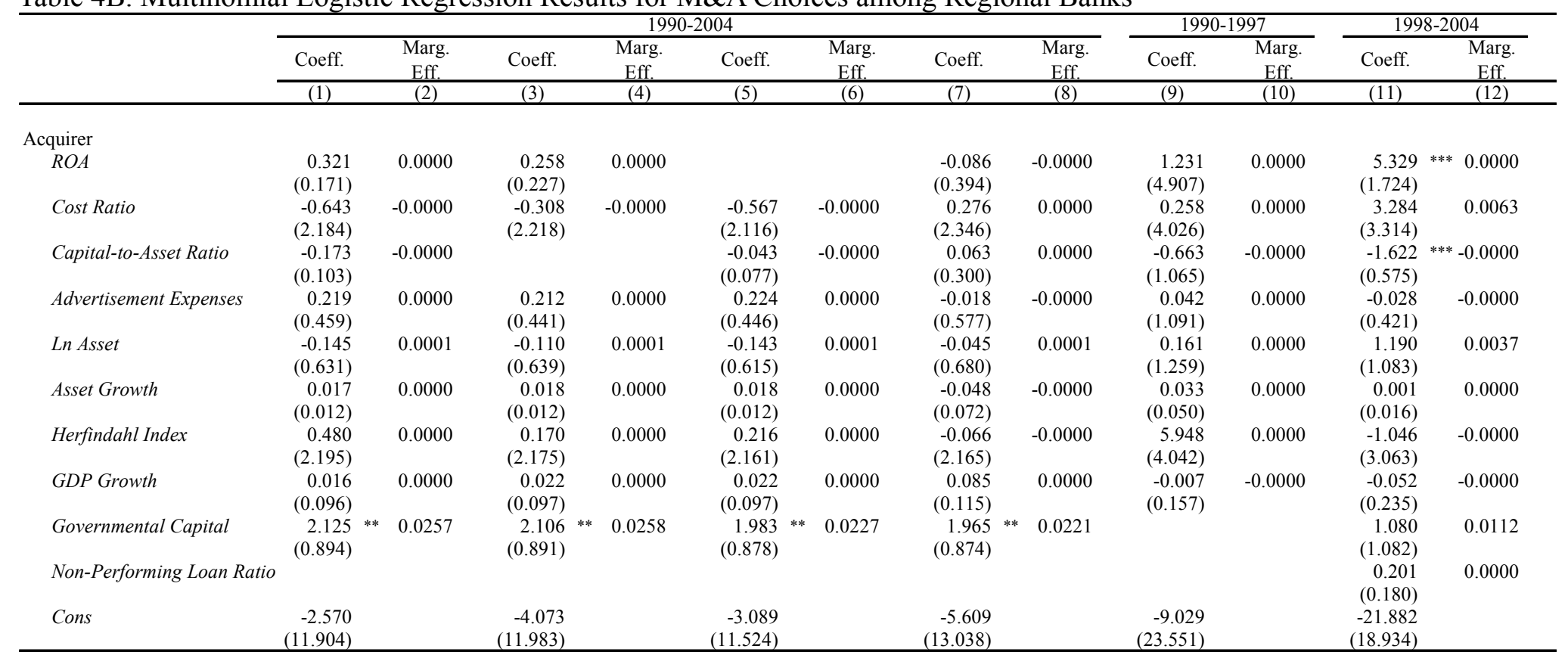


Table 4B. (Continued from previous page)

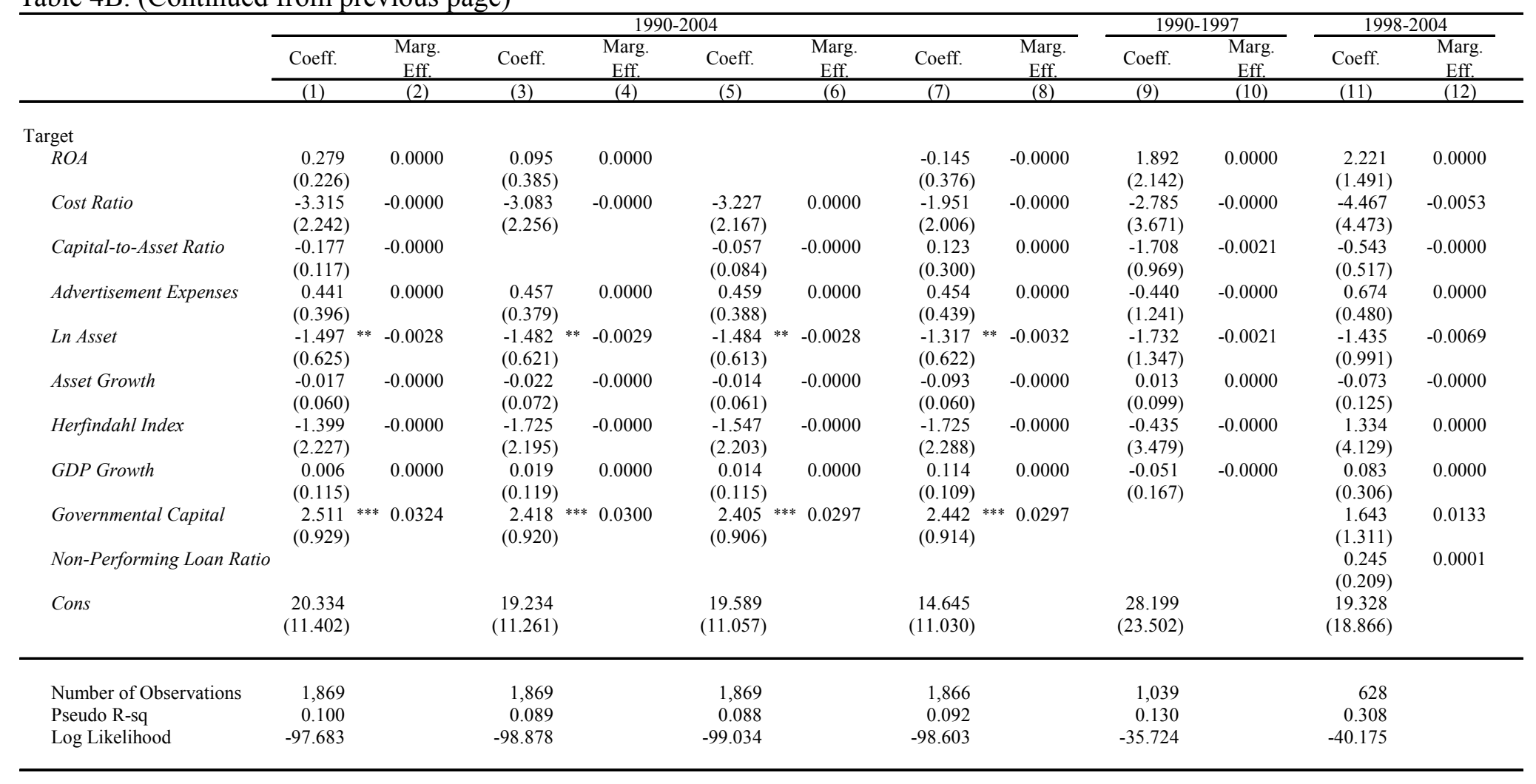

See the notes to Table $4 \mathrm{~A}$.

Independent variables are lagged one year for columns (1)-(6) and (9)-(12), while they are lagged two years for columns (7) and (8). 
Table 4C. Multinomial Logistic Regression Results for M\&A Choices among Shinkin Banks

\begin{tabular}{|c|c|c|c|c|c|c|c|c|c|c|c|c|}
\hline & \multicolumn{8}{|c|}{$1990-2002$} & \multicolumn{2}{|c|}{$1990-1997$} & \multicolumn{2}{|c|}{$1998-2002$} \\
\hline & Coeff. & $\begin{array}{l}\text { Marg. } \\
\text { Eff. }\end{array}$ & Coeff. & $\begin{array}{l}\text { Marg. } \\
\text { Eff. }\end{array}$ & Coeff. & $\begin{array}{l}\text { Marg. } \\
\text { Eff. }\end{array}$ & Coeff. & $\begin{array}{l}\text { Marg. } \\
\text { Eff. }\end{array}$ & Coeff. & $\begin{array}{l}\text { Marg. } \\
\text { Eff. }\end{array}$ & Coeff. & $\begin{array}{c}\text { Marg. } \\
\text { Eff. }\end{array}$ \\
\hline & $(1)$ & $(2)$ & (3) & $(4)$ & $(5)$ & $(6)$ & (7) & (8) & (9) & (10) & (11) & (12) \\
\hline \multicolumn{13}{|l|}{ Acquirer } \\
\hline$R O A$ & $\begin{array}{c}0.113 \\
(0.151)\end{array}$ & 0.0000 & $\begin{array}{c}0.050 \\
(0.115)\end{array}$ & 0.0000 & & & $\begin{array}{c}0.089 \\
(0.159)\end{array}$ & 0.0000 & $\begin{array}{l}-0.447 \\
(1.528)\end{array}$ & 0.0000 & $\begin{array}{c}0.072 \\
(0.238)\end{array}$ & 0.0000 \\
\hline Cost Ratio & $\begin{array}{c}0.397 \\
(0.655)\end{array}$ & 0.0000 & $\begin{array}{c}0.504 \\
(0.631)\end{array}$ & 0.0000 & $\begin{array}{c}0.443 \\
(0.648)\end{array}$ & 0.0000 & $\begin{array}{c}0.571 \\
(0.640)\end{array}$ & 0.0000 & $\begin{array}{c}0.859 \\
(0.856)\end{array}$ & 0.0000 & $\begin{array}{c}0.036 \\
(1.076)\end{array}$ & 0.0000 \\
\hline Capital-to-Asset Ratio & $\begin{array}{l}-0.055 \\
(0.083)\end{array}$ & -0.0000 & & & $\begin{array}{l}-0.014 \\
(0.055)\end{array}$ & -0.0000 & $\begin{array}{l}-0.039 \\
(0.085)\end{array}$ & -0.0000 & $\begin{array}{l}-0.143 \\
(0.168)\end{array}$ & -0.0000 & $\begin{array}{c}0.051 \\
(0.110)\end{array}$ & 0.0000 \\
\hline Ln Asset & $\begin{array}{c}0.521 \\
(0.168)\end{array}$ & *** 0.0000 & $\begin{array}{l}0.546^{* * *} \\
(0.165)\end{array}$ & 0.0000 & $\begin{array}{c}0.534 \\
(0.167)\end{array}$ & *** 0.0000 & $\begin{array}{c}0.573 \\
(0.166)\end{array}$ & ** $\quad 0.0000$ & $\begin{array}{l}0.5411^{* *} \\
(0.215)\end{array}$ & 0.0000 & $\begin{array}{l}0.536^{* *} \\
(0.274)\end{array}$ & 0.0071 \\
\hline Asset Growth & $\begin{array}{l}-0.029 \\
(0.022)\end{array}$ & -0.0000 & $\begin{array}{l}-0.029 \\
(0.022)\end{array}$ & -0.0000 & $\begin{array}{l}-0.025 \\
(0.020)\end{array}$ & -0.0000 & $\begin{array}{l}-0.016 \\
(0.019)\end{array}$ & -0.0000 & $\begin{array}{l}-0.021 \\
(0.034)\end{array}$ & -0.0000 & $\begin{array}{l}-0.033 \\
(0.028)\end{array}$ & -0.0000 \\
\hline Herfindahl Index & $\begin{array}{c}0.495 \\
(0.789)\end{array}$ & 0.0000 & $\begin{array}{c}0.441 \\
(0.785)\end{array}$ & 0.0000 & $\begin{array}{c}0.439 \\
(0.786)\end{array}$ & 0.0000 & $\begin{array}{c}0.451 \\
(0.784)\end{array}$ & 0.0000 & $\begin{array}{c}0.746 \\
(1.082)\end{array}$ & 0.0000 & $\begin{array}{l}-0.138 \\
(1.209)\end{array}$ & -0.0000 \\
\hline GDP Growth & $\begin{array}{l}-0.021 \\
(0.039)\end{array}$ & -0.0000 & $\begin{array}{l}-0.018 \\
(0.039)\end{array}$ & -0.0000 & $\begin{array}{l}-0.019 \\
(0.039)\end{array}$ & -0.0000 & $\begin{array}{c}0.007 \\
(0.031)\end{array}$ & 0.0000 & $\begin{array}{c}0.006 \\
(0.038)\end{array}$ & 0.0000 & $\begin{array}{l}-0.149 \\
(0.093)\end{array}$ & -0.0000 \\
\hline M\&A Experience & $\begin{array}{c}0.989 \\
(0.334)\end{array}$ & *** 0.0161 & $\begin{array}{l}1.030^{* * *} \\
(0.328)^{*}\end{array}$ & 0.0171 & $\begin{array}{c}0.998 \\
(0.334)\end{array}$ & *** 0.0164 & $\begin{array}{c}1.009 \\
(0.332)\end{array}$ & *** 0.0163 & & & $\begin{array}{l}1.280^{* * *} \\
(0.422)^{* *}\end{array}$ & 0.0268 \\
\hline Non-Performing Loan Ratio & & & & & & & & & & & $\begin{array}{c}0.061 \\
(0.035)\end{array}$ & 0.0000 \\
\hline Cons & $\begin{array}{r}-14.915 \\
(4.074) \\
\end{array}$ & *** & $\begin{array}{c}-15.837^{* * *} \\
(3.858)\end{array}$ & & $\begin{array}{c}-15.422 \\
(4.000) \\
\end{array}$ & *** & $\begin{array}{c}-16.361 \\
(4.045) \\
\end{array}$ & *** & $\begin{array}{c}-15.6266^{* * *} \\
(5.276)\end{array}$ & & $\begin{array}{c}-15.6622^{* * *} \\
(6.735)\end{array}$ & \\
\hline
\end{tabular}


Table 4C. (Continued from previous page)

\begin{tabular}{|c|c|c|c|c|c|c|c|c|c|c|c|c|}
\hline & \multicolumn{8}{|c|}{$1990-2002$} & \multicolumn{2}{|c|}{ 1990-1997 } & \multicolumn{2}{|c|}{$1998-2002$} \\
\hline & Coeff. & $\begin{array}{l}\text { Marg. } \\
\text { Eff. }\end{array}$ & Coeff. & $\begin{array}{l}\text { Marg. } \\
\text { Eff. }\end{array}$ & Coeff. & $\begin{array}{l}\text { Marg. } \\
\text { Eff. }\end{array}$ & Coeff. & $\begin{array}{l}\text { Marg. } \\
\text { Eff. }\end{array}$ & Coeff. & $\begin{array}{c}\text { Marg. } \\
\text { Eff. }\end{array}$ & Coeff. & $\begin{array}{c}\text { Marg. } \\
\text { Eff. }\end{array}$ \\
\hline & (1) & (2) & (3) & (4) & (5) & (6) & (7) & (8) & (9) & (10) & (11) & (12) \\
\hline \multicolumn{13}{|l|}{ Target } \\
\hline$R O A$ & $\begin{array}{r}0.445 \\
(0.110\end{array}$ & ${ }^{* * *} 0.0000$ & $\begin{array}{c}0.079 \\
(0.055)\end{array}$ & 0.0000 & & & $\begin{array}{c}0.505 \\
(0.122)\end{array}$ & ${ }^{* * *} 0.0000$ & $\begin{array}{l}-3.783^{* * *} \\
(1.336)\end{array}$ & $* *-0.0000$ & $\begin{array}{l}0.549^{* * *} \\
(0.132)\end{array}$ & $* 0.0000$ \\
\hline Cost Ratio & $\begin{array}{l}-1.167 \\
(0.416\end{array}$ & $* * *-0.0002$ & $\begin{array}{l}-1.265 \\
(0.437)\end{array}$ & ${ }^{* * *}-0.0001$ & $\begin{array}{l}-1.356 \\
(0.437)\end{array}$ & ${ }^{* * *}-0.0001$ & $\begin{array}{l}-1.111 \\
(0.403)\end{array}$ & ${ }^{* * *} 0.0000$ & $\begin{array}{l}-1.3988^{* *} \\
(0.590)\end{array}$ & $* \quad-0.0000$ & $\begin{array}{l}-0.943 \\
(0.694)\end{array}$ & -0.0008 \\
\hline Capital-to-Asset Ratio & $\begin{array}{l}-0.284 \\
(0.072\end{array}$ & ${ }^{* * *}-0.0000$ & & & $\begin{array}{l}-0.043 \\
(0.040)\end{array}$ & -0.0000 & $\begin{array}{l}-0.304 \\
(0.073)\end{array}$ & ${ }^{* * *}-0.0000$ & $\begin{array}{l}-0.087 \\
(0.136)\end{array}$ & -0.0000 & $\begin{array}{l}-0.2366^{* *} \\
(0.093)\end{array}$ & -0.0000 \\
\hline Ln Asset & $\begin{array}{l}-0.955 \\
(0.141\end{array}$ & )$^{* * *}-0.0014$ & $\begin{array}{l}-0.876 \\
(0.137)\end{array}$ & ${ }^{* * *}-0.0012$ & $\begin{array}{l}-0.944 \\
(0.138)\end{array}$ & ${ }^{* * *}-0.0013$ & $\begin{array}{l}-0.868 \\
(0.136)\end{array}$ & )$^{* * *}-0.0010$ & $\begin{array}{l}-1.157^{\text {**** }} \\
(0.216)\end{array}$ & $* *-0.0011$ & $\begin{array}{l}-0.911^{* * *} \\
(0.212)^{*}\end{array}$ & * -0.0170 \\
\hline Asset Growth & $\begin{array}{l}-0.129 \\
(0.026\end{array}$ & ${ }^{* * *}-0.0000$ & $\begin{array}{l}-0.141 \\
(0.027)\end{array}$ & $* * *-0.0000$ & $\begin{array}{l}-0.098 \\
(0.025)\end{array}$ & ${ }^{* * *}-0.0000$ & $\begin{array}{l}-0.121 \\
(0.025)\end{array}$ & ${ }^{* * *}-0.0000$ & $\begin{array}{l}-0.037 \\
(0.031)\end{array}$ & -0.0000 & $\begin{array}{l}-0.1588^{* * *} \\
(0.046)\end{array}$ & $*-0.0000$ \\
\hline Herfindahl Index & $\begin{array}{l}-2.588 \\
(0.753\end{array}$ & ${ }^{* * *}-0.0003$ & $\begin{array}{l}-2.701 \\
(0.756)\end{array}$ & ${ }^{* * *}-0.0000$ & $\begin{array}{l}-2.890 \\
(0.753)\end{array}$ & ${ }^{* * *}-0.0000$ & $\begin{array}{l}-2.450 \\
(0.736)\end{array}$ & )$^{* * *}-0.0000$ & $\begin{array}{l}-2.426 \\
(1.180)\end{array}$ & $* \quad-0.0000$ & $\begin{array}{l}-3.663^{* * *} \\
(1.105)\end{array}$ & $*-0.0000$ \\
\hline GDP Growth & $\begin{array}{l}-0.066 \\
(0.040\end{array}$ & -0.0000 & $\begin{array}{l}-0.048 \\
(0.041)\end{array}$ & -0.0000 & $\begin{array}{l}-0.065 \\
(0.039)\end{array}$ & -0.0000 & $\begin{array}{l}-0.004 \\
(0.036)\end{array}$ & -0.0000 & $\begin{array}{l}-0.054 \\
(0.057)\end{array}$ & -0.0000 & $\begin{array}{l}-0.052 \\
(0.088)\end{array}$ & -0.0000 \\
\hline M\&A Experience & $\begin{array}{l}-0.369 \\
(0.663\end{array}$ & -0.0042 & $\begin{array}{l}-0.166 \\
(0.641)\end{array}$ & -0.0022 & $\begin{array}{l}-0.398 \\
(0.721)\end{array}$ & -0.0045 & $\begin{array}{l}-0.369 \\
(0.622)\end{array}$ & -0.0043 & & & $\begin{array}{l}-0.282 \\
(0.666)\end{array}$ & -0.0051 \\
\hline Non-Performing Loan Ratio & & & & & & & & & & & $\begin{array}{l}0.112 \\
(0.028)\end{array}$ & * 0.0000 \\
\hline Cons & $\begin{array}{l}17.821 \\
(2.971\end{array}$ & & $\begin{array}{l}15.151 \\
(2.926)\end{array}$ & & $\begin{array}{l}16.835 \\
(2.972)\end{array}$ & & $\begin{array}{l}16.125 \\
(2.865)\end{array}$ & & $\begin{array}{l}21.240 \\
(4.288)\end{array}$ & & $\begin{array}{l}15.637^{* * *} \\
(4.763)^{*}\end{array}$ & \\
\hline Number of Observations & 5,626 & & 5,626 & & 5,626 & & 5,758 & & 3,432 & & 2,167 & \\
\hline Pseudo R-sq & 0.098 & & 0.087 & & 0.086 & & 0.085 & & 0.098 & & 0.158 & \\
\hline Log Likelihood & -681.741 & & -690.583 & & -691.122 & & -706.882 & & -327.212 & & -320.765 & \\
\hline
\end{tabular}

See the notes to Table $4 \mathrm{~A}$.

Independent variables are lagged one year for columns (1)-(6) and (9)-(12), while they are lagged two years for columns (7) and (8). 
Table 5A. Post-Merger Performance of Major Banks

\begin{tabular}{|c|c|c|c|c|c|c|}
\hline \multirow[t]{2}{*}{ Change from: } & \multicolumn{4}{|c|}{ Pre-Merger Combined Bank } & \multirow{2}{*}{\multicolumn{2}{|c|}{$\begin{array}{c}\begin{array}{c}\text { Pre-Merger } \\
\text { Acquirer }\end{array} \\
1990-2004 \\
\end{array}$}} \\
\hline & \multicolumn{2}{|c|}{$1990-2004$} & 1990-1997 & $1998-2004$ & & \\
\hline \multicolumn{7}{|l|}{$\overline{R O A}$} \\
\hline$\triangle R O A$ (3-year post-merger) & -0.200 & & & & -0.212 & \\
\hline$\triangle R O A$ (5-year post-merger) & 0.149 & & & & 0.125 & \\
\hline$\triangle R O A$ (post-merger average) & -0.219 & & 0.150 & -0.377 & -0.230 & \\
\hline \multicolumn{7}{|l|}{ Cost Ratio } \\
\hline$\Delta$ Cost Ratio (3-year post-merger) & -0.015 & & & & -0.054 & \\
\hline$\Delta$ Cost Ratio (5-year post-merger) & -0.058 & & & & -0.124 & \\
\hline$\Delta$ Cost Ratio (post-merger average) & -0.018 & & 0.015 & -0.033 & -0.058 & \\
\hline \multicolumn{7}{|l|}{ Fees and Commissions } \\
\hline$\Delta$ Fees and Commissions (3-year post-merger) & 0.079 & & & & -0.032 & \\
\hline$\Delta$ Fees and Commissions (5-year post-merger) & 0.110 & & & & 0.048 & \\
\hline$\Delta F e e s$ and Commissions (post-merger average) & 0.006 & & 0.065 & -0.024 & -0.029 & \\
\hline \multicolumn{7}{|l|}{ Loan-to-Asset Ratio } \\
\hline LLoan-to-Asset Ratio (3-year post-merger) & -0.235 & & & & -0.398 & \\
\hline$\Delta$ Loan-to-Asset Ratio (5-year post-merger) & 2.498 & & & & 1.817 & \\
\hline$\Delta$ Loan-to-Asset Ratio (post-merger average) & -1.037 & & 0.580 & -1.730 & -1.200 & \\
\hline \multicolumn{7}{|l|}{ Loans to SMEs } \\
\hline$\triangle$ Loans to SMEs (3-year post-merger) & 1.700 & $\mathrm{~b}$ & & & -1.850 & \\
\hline$\triangle$ Loans to SMEs (5-year post-merger) & -0.384 & & & & -4.909 & \\
\hline ALoans to SMEs (post-merger average) & 1.727 & $b^{* *}$ & $1.064 \mathrm{~b}$ & 2.390 & -2.047 & \\
\hline \multicolumn{7}{|l|}{ Loan Growth Rate } \\
\hline ALoan Growth Rate (3-year post-merger) & -2.760 & & & & -3.784 & \\
\hline$\Delta$ Loan Growth Rate (5-year post-merger) & -4.478 & & & & -6.387 & \\
\hline$\Delta$ Loan Growth Rate (post-merger average) & -3.058 & $b^{* *}$ & 0.014 & $-4.375 a^{* *}$ & -4.082 & $\mathrm{~b}^{* *}$ \\
\hline \multicolumn{7}{|l|}{ Deposit Interest Rate } \\
\hline$\Delta$ Deposit Interest Rate (3-year post-merger) & 0.008 & & & & 0.114 & \\
\hline$\Delta$ Deposit Interest Rate (5-year post-merger) & -0.354 & & & & -0.249 & \\
\hline$\Delta$ Deposit Interest Rate (post-merger average) & -0.058 & & 0.023 & -0.093 & 0.048 & \\
\hline \multicolumn{7}{|l|}{ Loan Interest Rate } \\
\hline$\Delta$ Loan Interest Rate (3-year post-merger) & 0.062 & & & & 0.075 & \\
\hline$\Delta$ Loan Interest Rate (5-year post-merger) & -0.057 & & & & -0.010 & \\
\hline$\Delta$ Loan Interest Rate (post-merger average) & -0.001 & & 0.167 & -0.073 & 0.012 & \\
\hline \multicolumn{7}{|l|}{ Capital-to-Asset Ratio } \\
\hline$\Delta$ Capital-to-Asset Ratio (3-year post-merger) & -1.319 & $a^{* *}$ & & & -1.342 & $a^{* *}$ \\
\hline ACapital-to-Asset Ratio (5-year post-merger) & -0.509 & & & & -0.498 & \\
\hline$\Delta$ Capital-to-Asset Ratio (post-merger average) & -1.158 & $a^{* * *}$ & -0.432 & $-1.470 \mathrm{a}^{* *}$ & -1.181 & $\mathrm{a}^{* * *}$ \\
\hline \multicolumn{7}{|l|}{ Risk-Based Capital Ratio (BIS) } \\
\hline ARisk-Based Capital Ratio (BIS) (3-year post-merger) & -2.108 & $\mathrm{~b}$ & & & -1.788 & $\mathrm{~b}$ \\
\hline ARisk-Based Capital Ratio (BIS) (5-year post-merger) & & & & & & \\
\hline$\triangle$ Risk-Based Capital Ratio (BIS) (post-merger average) & -1.376 & & & -1.376 & -1.104 & \\
\hline \multicolumn{7}{|l|}{ Non-Performing Loan Ratio (BL) } \\
\hline $\begin{array}{l}\Delta \text { ANon-Performing Loan Ratio }(B L) \text { (3-year post-merger) } \\
\text { ANon-Performing Loan Ratio (BL) (5-year post-merger) }\end{array}$ & 4.118 & $\mathrm{~b}$ & & & 4.301 & \\
\hline$\Delta$ Non-Performing Loan Ratio (BL) (post-merger average) & 3.697 & $\mathrm{~b}$ & & $3.697 \mathrm{~b}$ & 3.880 & $\mathrm{~b}^{* *}$ \\
\hline \multicolumn{7}{|l|}{ Non-Performing Loan Ratio (FRL) } \\
\hline $\begin{array}{l}\triangle \text { Non-Performing Loan Ratio (FRL) (3-year post-merger) } \\
\text { ANon-Performing Loan Ratio (FRL) (5-year post-merger) }\end{array}$ & 3.589 & $\mathrm{~b}$ & & & 3.835 & \\
\hline$\triangle$ Non-Performing Loan Ratio (FRL) (post-merger average) & 3.202 & & & 3.202 & 3.448 & $\mathrm{~b}^{* *}$ \\
\hline Advertisement Expenses & & & & & & \\
\hline$\Delta$ Advertisement Expenses (3-year post-merger) & -0.268 & & & & -0.339 & \\
\hline$\Delta$ Advertisement Expenses (5-year post-merger) & 0.243 & & & & 0.038 & \\
\hline$\Delta$ Advertisement Expenses (post-merger average) & -0.164 & & 0.240 & -0.337 & -0.234 & \\
\hline Asset Growth & & & & & & \\
\hline$\Delta$ Asset Growth (3-year post-merger) & -3.450 & & & & -4.497 & \\
\hline$\Delta$ Asset Growth (5-year post-merger) & -3.891 & & & & -5.557 & \\
\hline$\Delta$ Asset Growth (post-merger average) & -2.617 & & 1.973 & $-4.585 \mathrm{a}^{* *}$ & -3.665 & \\
\hline
\end{tabular}

Notes

1. The columns under the heading of "Pre-Merger Combined Bank" denote the average change from the pre-merger hypothetical combined bank that is a weighted average of an acquirer and a target.

2. The column under the heading of "Pre-Merger Acquirer" denotes the average changes from the pre-merger acquirer.

3. $\Delta \mathrm{X}$ ( $\mathrm{t}$-year post-merger) is the difference of the variable $\mathrm{X}$ between $\mathrm{t}$-year post-merger and the pre-merger 
average over five years (or less if data is not available).

4. $\Delta \mathrm{X}$ (post-merger average) is the difference between $\mathrm{X}$ (post-merger average) and $\mathrm{X}$ (pre-merger average), where $\mathrm{X}$ (post-merger average) is the post-merger average of the variable $\mathrm{X}$ over five years (or less if data is not available) and $\mathrm{X}$ (pre-merger average) is the pre-merger average of the variable $\mathrm{X}$ over five years (or less if data not available).

5. $\mathrm{a}$ and $\mathrm{b}$ denote significance at the $1 \%$ and $5 \%$ level, respectively, for the null hypothesis that $\Delta \mathrm{X}$ (or $\mathrm{X}$ ) has zero mean.

6. $* * *$ and $* *$ denote significance at the $1 \%$ and $5 \%$ level, respectively, for the Wilcoxon signed-rank test for the null hypothesis that $\Delta \mathrm{X}$ (or $\mathrm{X}$ ) has median zero. 
Table 5B. Post-Merger Performance of Regional Banks

\begin{tabular}{|c|c|c|c|c|}
\hline & \multicolumn{3}{|c|}{ Weighted average } & Acquirer \\
\hline & $1990-2004$ & \multirow[t]{2}{*}{$1990-1997$} & $1998-2004$ & $1990-2004$ \\
\hline \multicolumn{4}{|l|}{$\overline{R O A}$} & \\
\hline$\triangle R O A(3$-year post-merger) & -1.869 & & & -1.934 \\
\hline$\triangle R O A$ (5-year post-merger) & $0.504 \mathrm{~b}$ & & & $0.481 \mathrm{~b}$ \\
\hline$\triangle R O A$ (post-merger average) & -0.471 & 0.067 & -0.793 & -0.530 \\
\hline \multicolumn{5}{|l|}{ Cost Ratio } \\
\hline$\Delta$ Cost Ratio (3-year post-merger) & -0.003 & & & 0.021 \\
\hline$\Delta$ Cost Ratio (5-year post-merger) & -0.084 & & & -0.045 \\
\hline$\Delta$ Cost Ratio (post-merger average) & 0.009 & -0.064 & 0.053 & 0.021 \\
\hline \multicolumn{5}{|l|}{ Fees and Commissions } \\
\hline$\Delta F e e s$ and Commissions (3-year post-merger) & 0.013 & & & -0.001 \\
\hline$\Delta F e e s$ and Commissions (5-year post-merger) & -0.003 & & & -0.010 \\
\hline$\Delta$ Fees and Commissions (post-merger average) & 0.034 & -0.005 & $0.057 * *$ & 0.014 \\
\hline \multicolumn{5}{|l|}{$\overline{\text { Loan-to-Asset Ratio }}$} \\
\hline ALoan-to-Asset Ratio (3-year post-merger) & -2.131 & & & -0.623 \\
\hline$\Delta$ Loan-to-Asset Ratio (5-year post-merger) & -3.387 & & & -2.100 \\
\hline$\Delta$ Loan-to-Asset Ratio (post-merger average) & -2.163 & -2.299 & -2.082 & -1.303 \\
\hline \multicolumn{5}{|l|}{ Loans to SMEs } \\
\hline$\triangle$ Loans to SMEs (3-year post-merger) & -1.556 & & & -1.079 \\
\hline$\triangle$ Loans to SMEs (5-year post-merger) & -1.320 & & & -0.721 \\
\hline$\triangle$ Loans to SMEs (post-merger average) & -0.335 & -1.310 & 0.249 & 0.415 \\
\hline \multicolumn{5}{|l|}{ Loan Growth Rate } \\
\hline$\Delta$ Loan Growth Rate (3-year post-merger) & -3.471 & & & -3.587 \\
\hline$\Delta$ Loan Growth Rate (5-year post-merger) & -1.928 & & & -2.549 \\
\hline$\Delta$ Loan Growth Rate (post-merger average) & -0.846 & -0.974 & -0.768 & -0.818 \\
\hline \multicolumn{5}{|l|}{ Deposit Interest Rate } \\
\hline$\Delta$ Deposit Interest Rate (3-year post-merger) & -0.010 & & & 0.015 \\
\hline$\Delta$ Deposit Interest Rate (5-year post-merger) & 0.125 & & & 0.143 \\
\hline$\Delta$ Deposit Interest Rate (post-merger average) & -0.006 & 0.025 & -0.024 & 0.023 \\
\hline \multicolumn{5}{|l|}{ Loan Interest Rate } \\
\hline$\Delta$ Loan Interest Rate (3-year post-merger) & $0.187 \mathrm{~b}$ & & & 0.269 \\
\hline$\Delta$ Loan Interest Rate (5-year post-merger) & $0.177 \mathrm{~b}$ & & & 0.221 \\
\hline$\Delta$ Loan Interest Rate (post-merger average) & 0.069 & 0.174 & 0.007 & $0.178 \mathrm{~b}^{* *}$ \\
\hline \multicolumn{5}{|l|}{ Capital-to-Asset Ratio } \\
\hline$\Delta$ Capital-to-Asset Ratio (3-year post-merger) & -0.371 & & & -0.416 \\
\hline ACapital-to-Asset Ratio (5-year post-merger) & -0.202 & & & -0.283 \\
\hline$\Delta$ Capital-to-Asset Ratio (post-merger average) & $-0.892 \mathrm{~b}^{* *}$ & -0.135 & $-1.347 \mathrm{a}^{* *}$ & $-0.995 \mathrm{~b}^{* *}$ \\
\hline \multicolumn{5}{|l|}{ Risk-Based Capital Ratio (BIS) } \\
\hline \multicolumn{5}{|l|}{$\Delta$ Risk-Based Capital Ratio (BIS) (3-year post-merger) } \\
\hline ARisk-Based Capital Ratio (BIS) (5-year post-merger) & & & & \\
\hline DRisk-Based Capital Ratio (BIS) (post-merger average) & -0.543 & & -0.543 & -0.718 \\
\hline Non-Performing Loan Ratio (BL) & & & & \\
\hline$\triangle$ Non-Performing Loan Ratio (BL) (3-year post-merger) & & & & \\
\hline$\triangle$ Non-Performing Loan Ratio (BL) (5-year post-merger) & & & & \\
\hline$\triangle N o n$-Performing Loan Ratio (BL) (post-merger average) & 0.813 & & 0.813 & 0.870 \\
\hline Non-Performing Loan Ratio (FRL) & & & & \\
\hline$\triangle$ Non-Performing Loan Ratio (FRL) (3-year post-merger) & & & & \\
\hline$\triangle N o n$-Performing Loan Ratio (FRL) (5-year post-merger) & & & & \\
\hline$\triangle N o n$-Performing Loan Ratio (FRL) (post-merger averag & 1.478 & & 1.478 & 0.560 \\
\hline Advertisement Expenses & & & & \\
\hline$\Delta$ Advertisement Expenses (3-year post-merger) & -0.353 a & & & -0.300 \\
\hline$\Delta$ Advertisement Expenses (5-year post-merger) & $-0.251 \mathrm{~b}$ & & & -0.154 \\
\hline$\Delta$ Advertisement Expenses (post-merger average) & -0.052 & -0.203 & 0.038 & 0.064 \\
\hline Asset Growth & & & & \\
\hline$\Delta$ Asset Growth (3-year post-merger) & -2.223 & & & -2.018 \\
\hline$\Delta$ Asset Growth (5-year post-merger) & -1.652 & & & -2.126 \\
\hline$\Delta$ Asset Growth (post-merger average) & 0.242 & -0.158 & 0.482 & 0.298 \\
\hline
\end{tabular}

See the notes to Table 5A. 
Table 5C. Post-Merger Performance of Shinkin Banks

\begin{tabular}{|c|c|c|c|c|c|}
\hline & \multicolumn{3}{|c|}{ Weighted average } & \multirow{2}{*}{\multicolumn{2}{|c|}{$\begin{array}{c}\text { Acquirer } \\
1990-2002\end{array}$}} \\
\hline & $1990-2002$ & \multirow{2}{*}{$1990-1997$} & \multirow{2}{*}{$1998-2002$} & & \\
\hline$R O A$ & & & & & \\
\hline$\triangle R O A$ (3-year post-merger) & -0.032 & & & -0.047 & \\
\hline$\triangle R O A$ (5-year post-merger) & 0.107 & & & 0.093 & \\
\hline$\triangle R O A$ (post-merger average) & 0.003 & 0.064 & -0.098 & -0.019 & \\
\hline Cost Ratio & & & & & \\
\hline$\Delta$ Cost Ratio (3-year post-merger) & -0.002 & & & -0.011 & \\
\hline$\Delta$ Cost Ratio (5-year post-merger) & 0.011 & & & -0.014 & \\
\hline$\Delta$ Cost Ratio (post-merger average) & 0.000 & 0.018 & -0.029 & 0.000 & \\
\hline Fees and Commissions & & & & & \\
\hline$\Delta$ Fees and Commissions (3-year post-merger) & 0.004 & & & 0.003 & \\
\hline$\Delta$ Fees and Commissions (5-year post-merger) & 0.007 & & & 0.005 & \\
\hline$\Delta$ Fees and Commissions (post-merger average) & 0.003 & 0.003 & 0.003 & 0.003 & \\
\hline Loan-to-Asset Ratio & & & & & \\
\hline LLoan-to-Asset Ratio (3-year post-merger) & 0.718 & & & -0.120 & \\
\hline LLoan-to-Asset Ratio (5-year post-merger) & 1.127 & & & 0.186 & \\
\hline ALoan-to-Asset Ratio (post-merger average) & 0.765 & 0.328 & 1.492 & 0.178 & \\
\hline Loan Growth Rate & & & & & \\
\hline ALoan Growth Rate (3-year post-merger) & -0.916 & & & -1.833 & $a^{* * * *}$ \\
\hline ALoan Growth Rate (5-year post-merger) & -0.971 & & & -2.029 & \\
\hline$\triangle$ Loan Growth Rate (post-merger average) & -0.823 & -0.744 & -0.956 & -1.940 & $\mathrm{a}^{* * * *}$ \\
\hline Deposit Interest Rate & & & & & \\
\hline$\triangle D$ Deposit Interest Rate (3-year post-merger) & 0.037 & & & 0.052 & \\
\hline$\triangle$ Deposit Interest Rate (5-year post-merger) & 0.039 & & & 0.064 & \\
\hline$\triangle$ Deposit Interest Rate (post-merger average) & 0.022 & 0.049 & -0.021 & 0.029 & \\
\hline Loan Interest Rate & & & & & \\
\hline$\Delta$ Loan Interest Rate (3-year post-merger) & 0.084 & & & 0.052 & \\
\hline$\Delta$ Loan Interest Rate (5-year post-merger) & 0.088 & & & 0.045 & \\
\hline$\triangle$ Loan Interest Rate (post-merger average) & 0.062 & 0.079 & 0.033 & 0.040 & \\
\hline Capital-to-Asset Ratio & & & & & \\
\hline$\triangle$ Capital-to-Asset Ratio (3-year post-merger) & $-0.547 \mathrm{~b}^{* *}$ & & & -0.659 & $\mathrm{a}^{* * * *}$ \\
\hline ACapital-to-Asset Ratio (5-year post-merger) & -0.476 & & & -0.551 & \\
\hline$\Delta$ Capital-to-Asset Ratio (post-merger average) & $-0.510 a^{* * *}$ & $-0.487 b^{* *}$ & $-0.548 a^{* * *}$ & -0.625 & $a^{* * * *}$ \\
\hline Risk-Based Capital Ratio (BIS) & & & & & \\
\hline ARisk-Based Capital Ratio (BIS) (3-year post-merger) & -1.508 & & & -1.801 & \\
\hline ARisk-Based Capital Ratio (BIS) (5-year post-merger) & $-3.331 \mathrm{~b}$ & & & -3.354 & $\mathrm{~b}$ \\
\hline ARisk-Based Capital Ratio (BIS) (post-merger average) & $-0.969 \mathrm{a}^{* * *}$ & -1.820 & $-0.733 \mathrm{a}^{* * *}$ & -1.311 & \\
\hline Non-Performing Loan Ratio (BL) & & & & & \\
\hline$\triangle$ Non-Performing Loan Ratio (BL) (3-year post-merger) & 0.697 & & & 1.565 & \\
\hline$\triangle$ Non-Performing Loan Ratio $(B L)$ (5-year post-merger) & 0.842 & & & 1.338 & \\
\hline$\triangle$ Non-Performing Loan Ratio (BL) (post-merger average) & 0.625 & 0.094 & 0.782 & 1.426 & $\mathrm{~b}^{* *}$ \\
\hline Asset Growth & & & & & \\
\hline$\Delta$ Asset Growth (3-year post-merger) & -1.070 & & & -1.358 & \\
\hline$\Delta$ Asset Growth (5-year post-merger) & $-1.844 b^{* *}$ & & & -2.011 & $\mathrm{a}^{* *}$ \\
\hline$\Delta$ Asset Growth (post-merger average) & $-1.904 \mathrm{a}^{* * *}$ & $-1.462 b^{* *}$ & $-2.640 a^{* * *}$ & -2.543 & $\mathrm{a}^{* * * *}$ \\
\hline
\end{tabular}

See the notes to Table 5A. 
Figure 1A. Pre-Merger and Post-Merger Performances of Major Banks

ROA

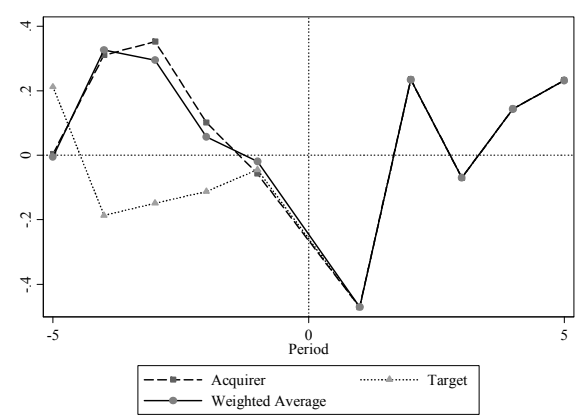

Fees and Commissions

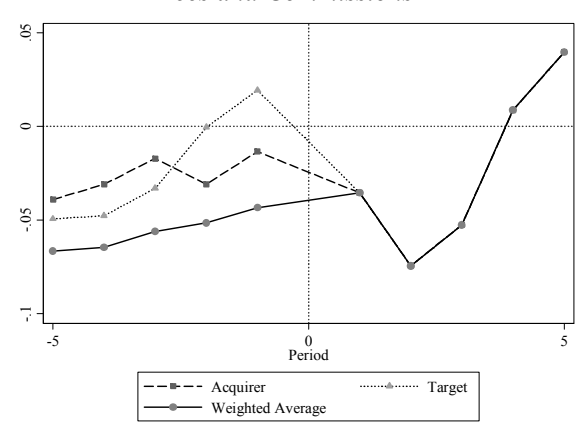

Loans to SMES

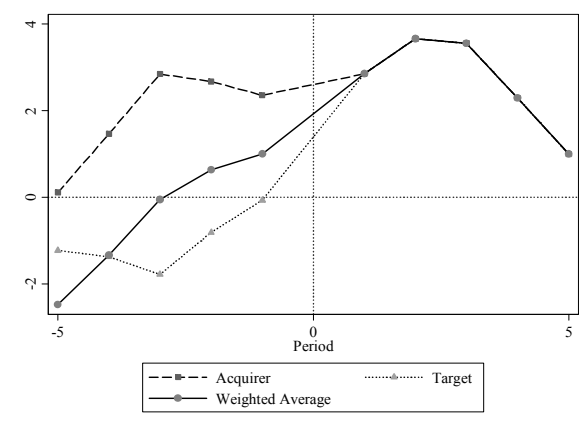

Deposit Interest Rate

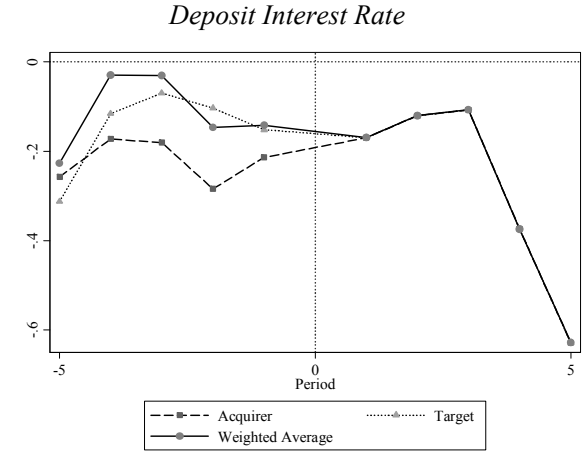

Cost Ratio

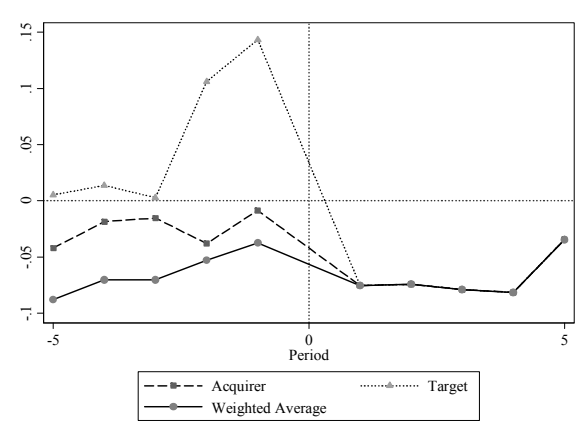

Loan-to-Asset Ratio

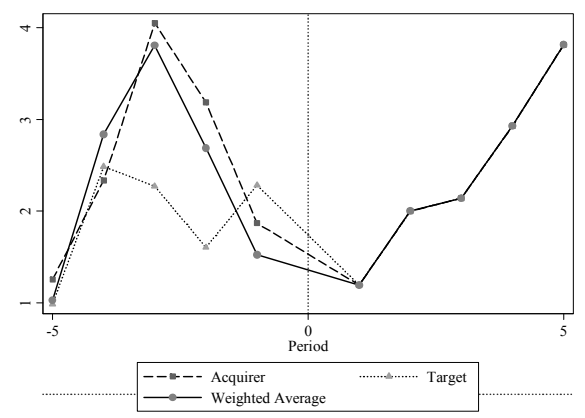

Loan Growth Rate

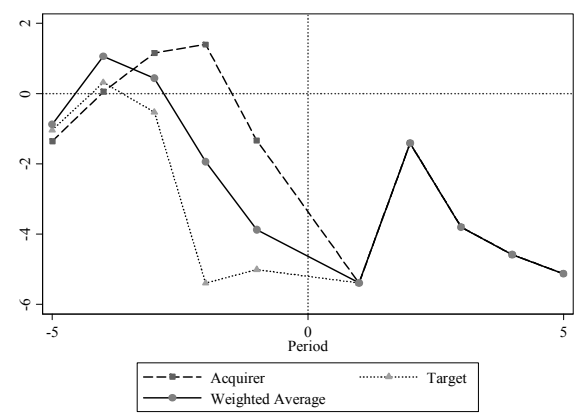

Loan Interest Rate

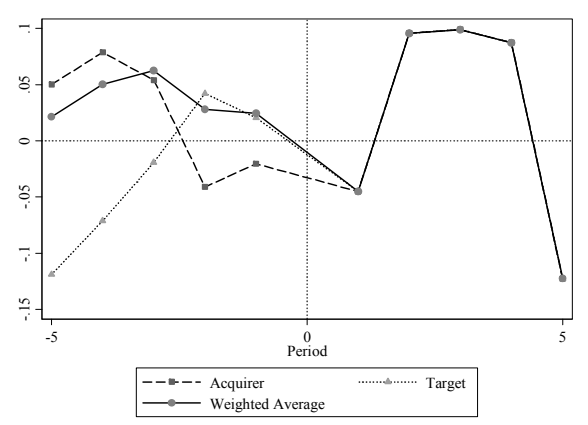


(Figure 1A. Continued from previous page)

Capital-to-Asset Ratio

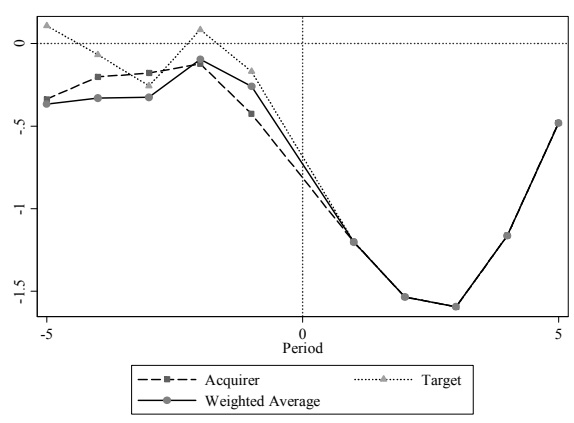

Non-Performing Loan Ratio (BL)

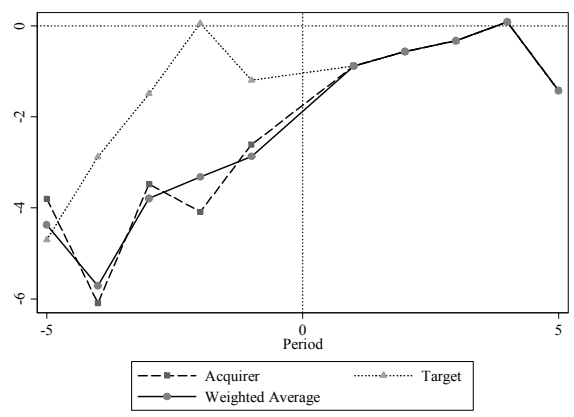

Advertisement Expenses

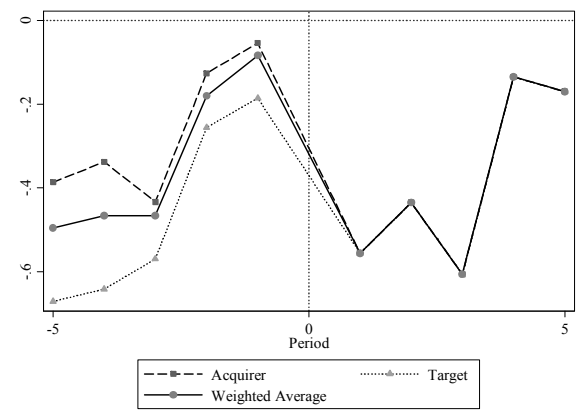

Risk-Based Capital Ratio (BIS)

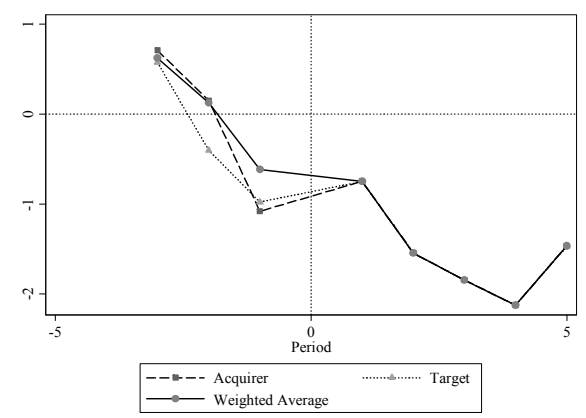

Non-Performing Loan Ratio (FRL)

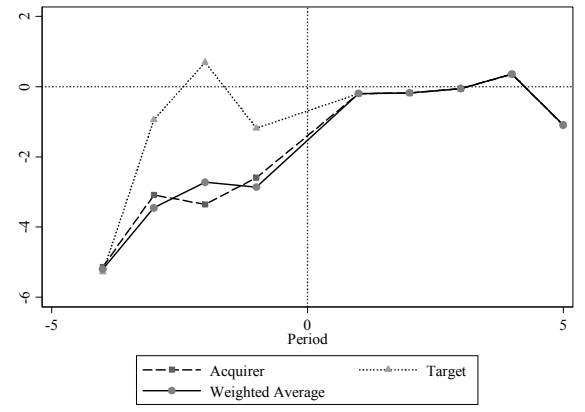

Asset Growth

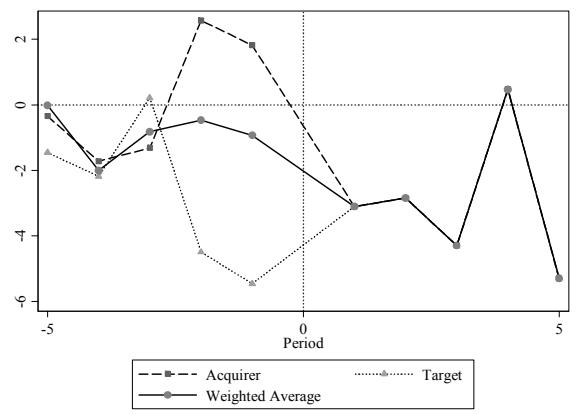

Notes

1. Period zero designates the year when the bank merger occurred. Negative periods denote pre-merger years and positive periods denote post-merger years.

2. We connect the period $(-1)$ value and period $(+1)$ value with a straight line.

3. Weighted average denotes the hypothetical pre-merger combined bank, calculated as a weighted average of the acquirer and the target with their total assets being used as weights. 
Figure 1B. Pre-Merger and Post-Merger Performances of Regional Banks
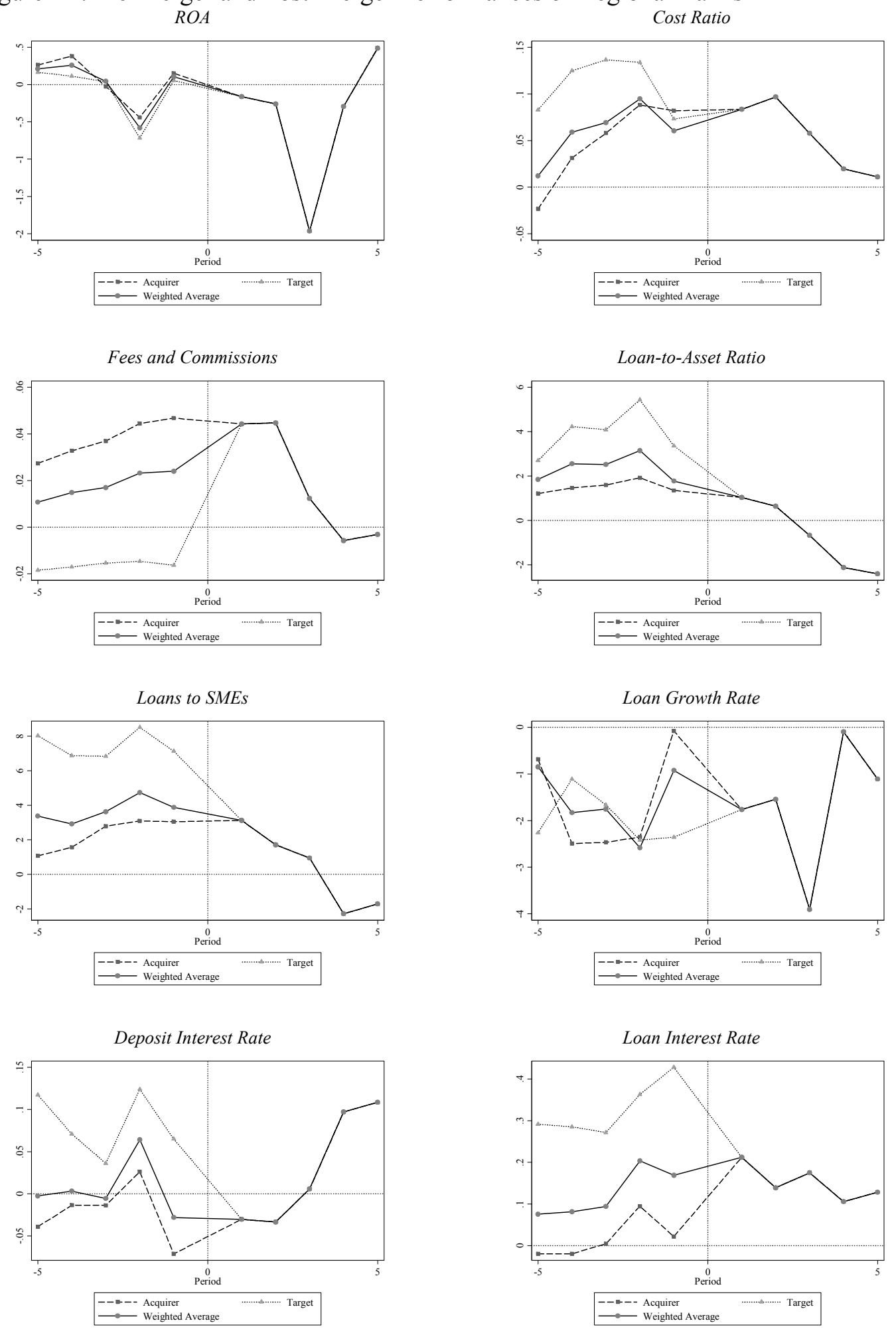
(Figure 1B. Continued from previous page) Capital-to-Asset Ratio

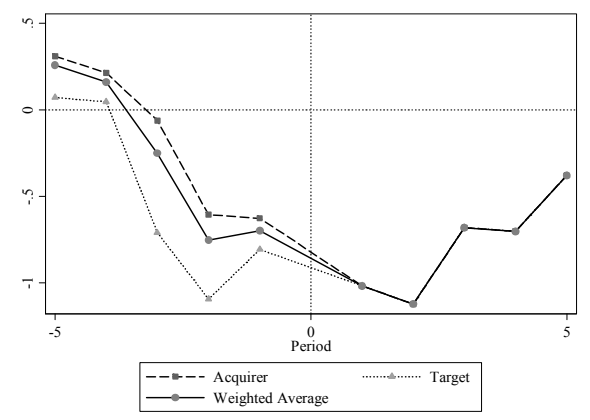

Non-Performing Loan Ratio (BL)

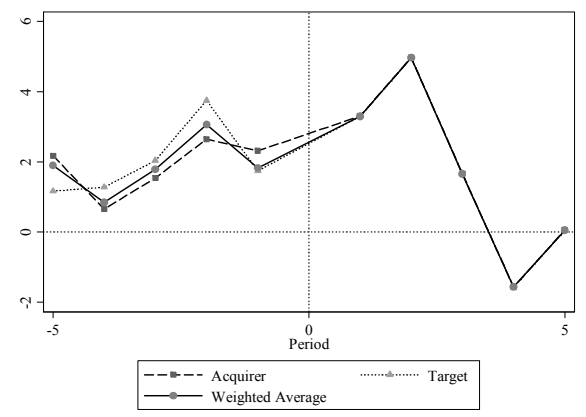

Advertisement Expenses

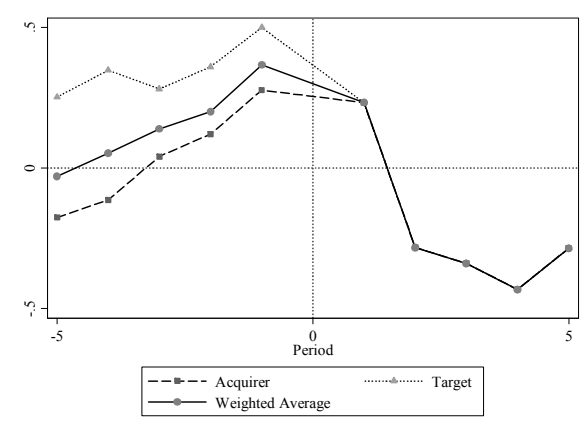

See the notes to Figure 1A.

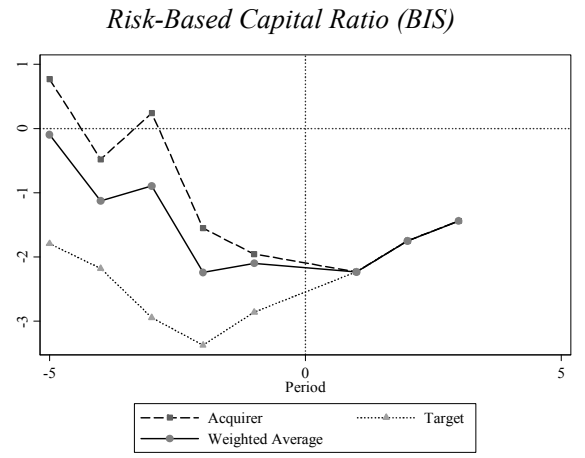

Non-Performing Loan Ratio (FRL)

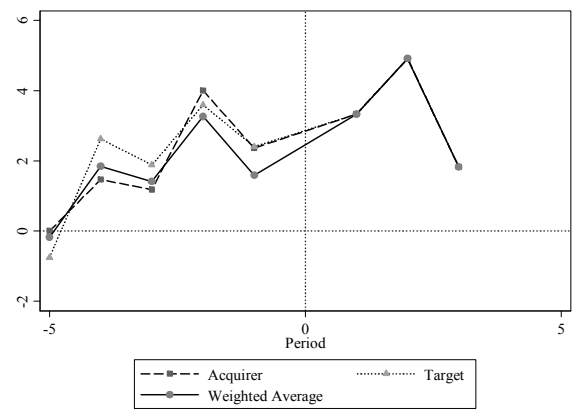

Asset Growth

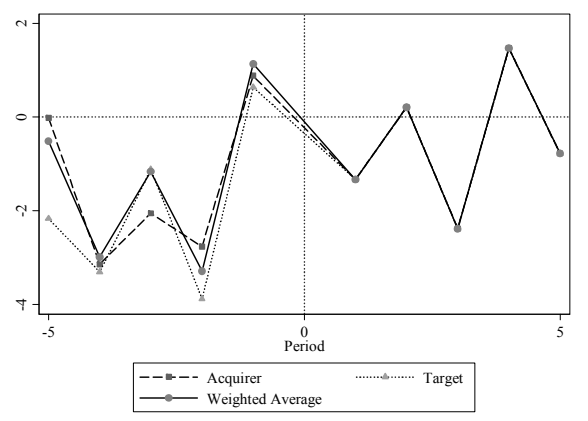


Figure 1C. Pre-Merger and Post-Merger Performances of Shinkin Banks
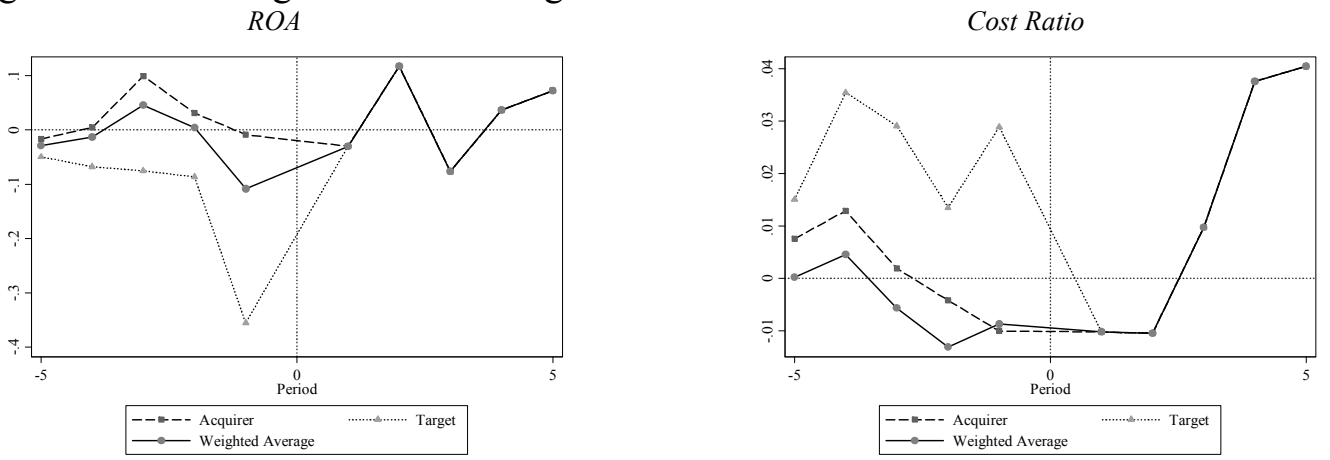

Fees and Commissions
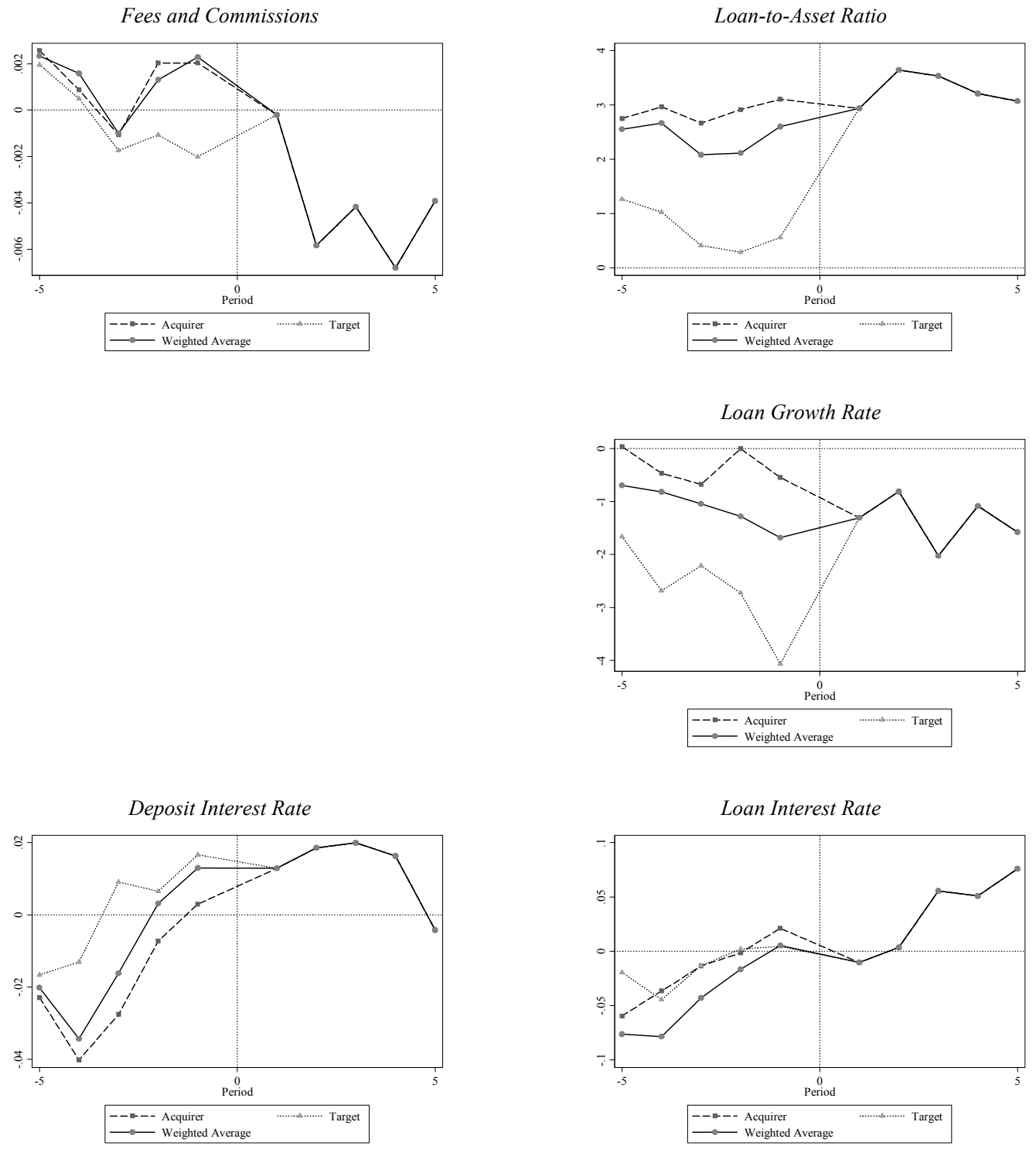
(Figure 1C. Continued from previous page)

Capital-to-Asset Ratio

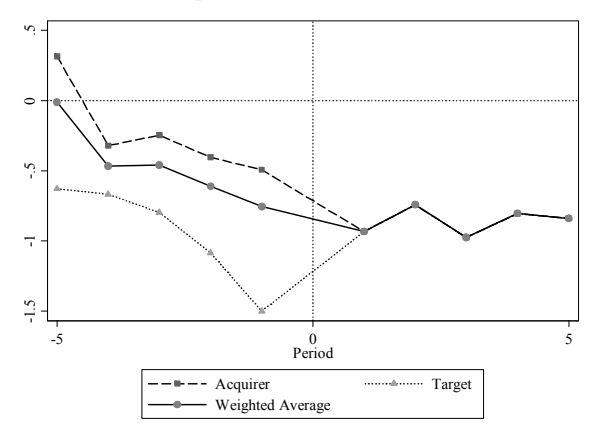

Non-Performing Loan Ratio (BL)

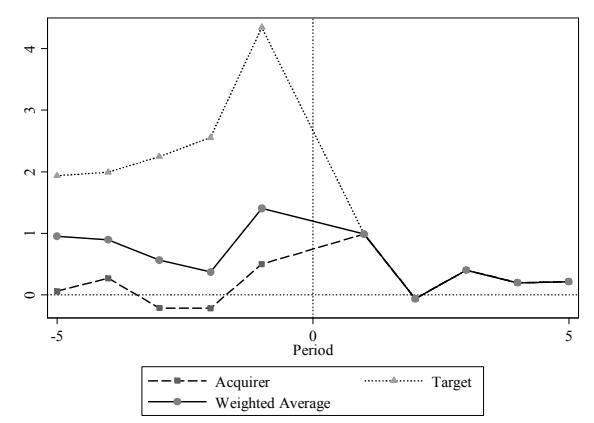

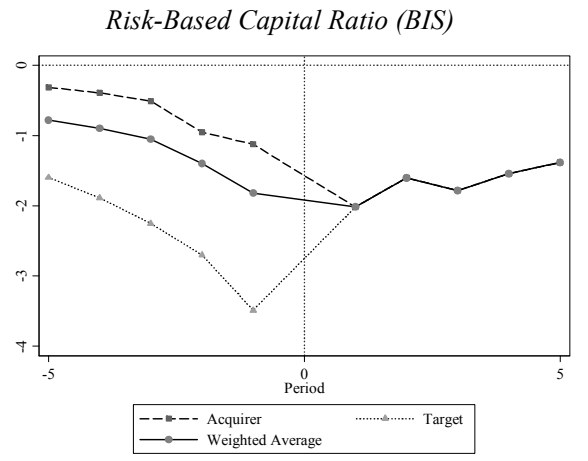

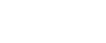

